\title{
Revealing the identity of Mordellistena minima and M. pseudorhenana (Coleoptera: Mordellidae) based on re-examined type material and DNA barcodes, with new distributional records and comments on morphological variability
}

\author{
Dávid Selnekovič ${ }^{1 *}$, Katarína Goffová ${ }^{1}$, Ján Kodada ${ }^{1}$, and Roberta Improta ${ }^{2}$ \\ ${ }^{1}$ Department of Zoology, Comenius University in Bratislava Faculty of Natural Sciences, Ilkovičova 6, Bratislava, SK-84215, \\ Slovakia and ${ }^{2}$ Museo Zoologico, Centro Musei delle Scienze Naturali e Fisiche dell'Università degli Studi di Napoli Federico II, \\ Via Mezzocannone 8, Naples, IT-80134, Italy \\ ${ }^{\star}$ Corresponding author. Email: david.selnekovic@uniba.sk
}

(Received 14 July 2020; accepted 21 September 2020; first published online 10 March 2021)

\begin{abstract}
The current interpretation of two common European species, Mordellistena minima Costa, 1854 and M. pseudorhenana Ermisch, 1977, is based on misidentification. The confusion regarding the identity of the species is fixed based on the revised type material. Here, the species are redescribed, and diagnostic characters are provided. Mordellistena pseudorhenana is revalidated. Mordellistena emeryi Schilsky, 1895 is recognised as a new synonym of M. minima. Mordellistena sajoi Ermisch, 1977 is recognised as a new synonym of $M$. pseudorhenana. Lectotype and paralectotypes of M. emeryi are designated. Mordellistena pseudorhenana is reported for the first time from Bosnia and Herzegovina, Slovenia, and Switzerland. Two morphotypes of M. pseudorhenana differing in size and shape of the parameres are recognised. Morphological differences are quantified and displayed using principal component analysis. In addition, DNA barcodes have been used for the first time in family Mordellidae to examine the divergences between the species and to interpret the morphological variability observed in $M$. pseudorhenana. Low genetic divergences did not provide the evidence for considering the morphotypes as separate species. The discrepancy between the morphological and molecular evidence raises questions about the efficiency of the $\mathrm{CO} 1$ gene for Mordellidae identification and the stability of morphological traits conventionally used for species separation.
\end{abstract}

\section{Introduction}

The genus Mordellistena Costa, 1854 (Coleoptera: Mordellidae) is represented in Europe by approximately 170 species (Horák 2008; Odnosum 2009; Selnekovič and Kodada 2019; Selnekovič and Ruzzier 2019; Selnekovič and Improta 2020). Most of the common and widespread European species were described during the 19th century by Costa (1854), Mulsant (1856), Emery (1876), and Schilsky $(1894,1895,1898,1899)$. Their work was later followed up by specialists and prolific authors such as K. Ermisch, M.E. Franciscolo, and R. Batten, who greatly contributed to the knowledge of the family with descriptions of dozens of new species. Unfortunately, during our recent studies, it became clear that the type material of some previously described taxa remained unstudied, leading to several cases of incorrect species interpretations

Subject editor: Derek Sikes

Taxonomic paper: ZooBank Registration \#: urn:lsid:zoobank.org:pub:EE0D9FD3-24B9-4054-A786-83474C96C8F0

(C) The Author(s), 2021. Published by Cambridge University Press on behalf of the Entomological Society of Canada. This is an Open Access article, distributed under the terms of the Creative Commons Attribution licence (http://creativecommons.org/licenses/by/4.0/), which permits unrestricted re-use, distribution, and reproduction in any medium, provided the original work is properly cited. 


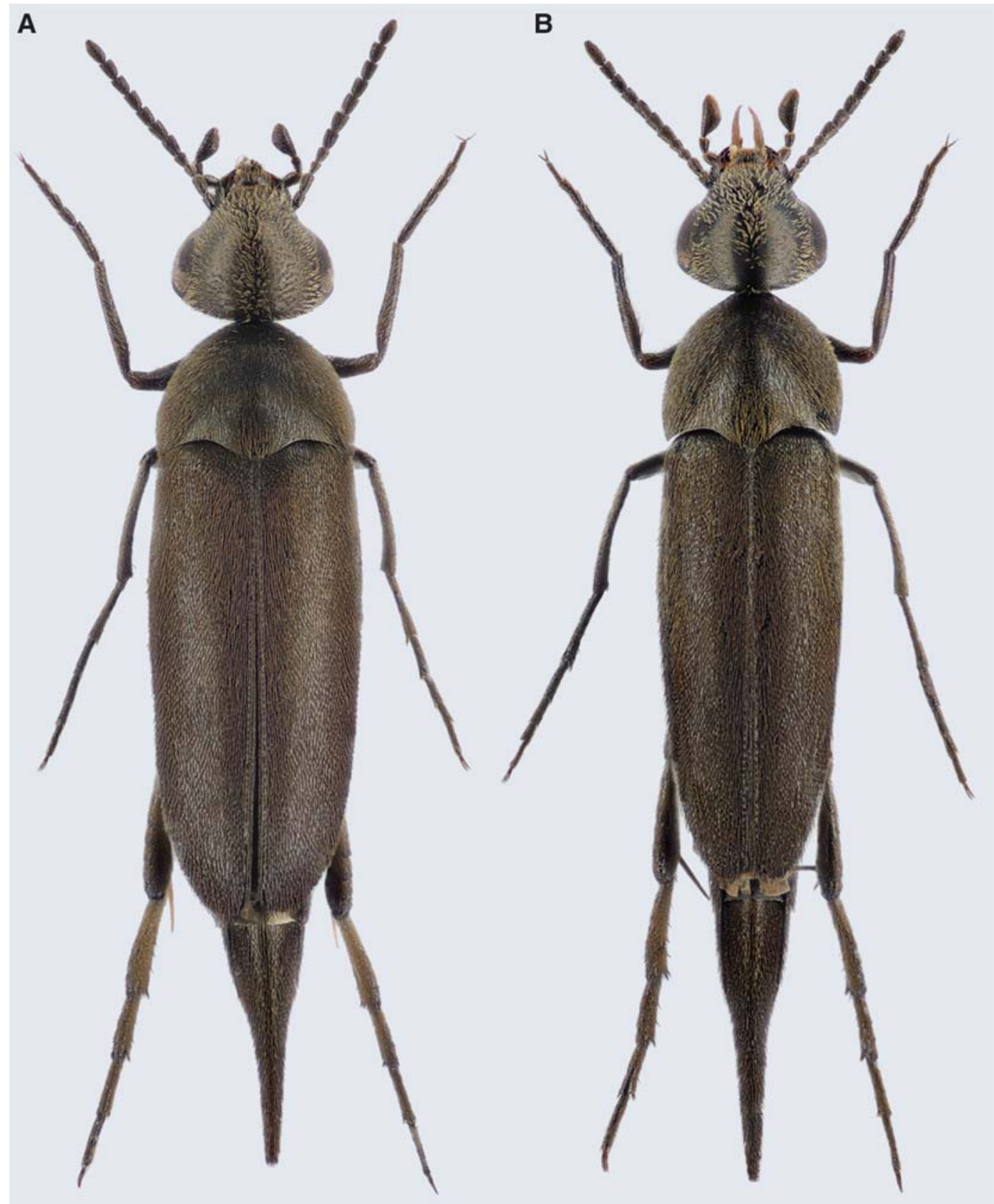

Fig. 1. A, Mordellistena minima Costa, 1854, male, body length: $2.4 \mathrm{~mm}$; B, Mordellistena pseudorhenana Ermisch, 1977, male, body length: $2.5 \mathrm{~mm}$.

and descriptions of taxa that already bore a name (Horák 1990, 1996; Selnekovič and Kodada 2019; Selnekovič and Improta 2020). Mordellistena minima Costa, 1854 (Fig. 1A) and M. pseudorhenana Ermisch, 1977 (Fig. 1B) discussed in the present paper may serve as examples.

Mordellistena minima was described by Costa (1854) based on a specimen from the island of Ischia, Italy. Later, Emery (1876) considered the type specimen of M. minima "just a small 
specimen of M. micans (Germar, 1817), which varies greatly in size". His opinion was then followed by all subsequent authors until Ermisch (1954) treated M. minima as a valid species but did not provide any description or diagnostic characters to separate it from its allies. Batten (1977), without seeing the type specimen, characterised M. minima based on a unique combination of characters: short antennomeres, long and pointed galea, and expanded protibiae in males. Subsequently, Batten (1980) examined the holotype of M. pseudorhenana Ermisch, 1977 and considered it to be conspecific with M. minima.

The re-examination of the type specimen of M. minima surprisingly revealed a unique set of characters that differ significantly from the abovementioned and currently accepted interpretation of the species as presented by Batten (1977). The present paper aims to resolve the confusion regarding the identity of $M$. minima and $M$. pseudorhenana and to provide redescriptions of both species based on the examined type material. We integrated morphometric and DNA barcode analyses to interpret the observed morphological variability in specimens of M. pseudorhenana. Furthermore, we have been able to add DNA barcodes for the first time to five species of the Mordellistena confinis species group, with recently re-examined and documented type material (Horák 1996; Selnekovič and Kodada 2019; Selnekovič and Improta 2020). This allowed us to examine the interspecific genetic divergences at the species-group level and set the baseline for future studies with the use of DNA markers.

\section{Materials and methods}

The present study is based on examination of 242 adult specimens, including a lectotype of Mordellistena minima Costa, 1854, a lectotype and paralectotypes of M. emeryi Schilsky, 1895, two syntypes of $M$. micans (Germar, 1813), a holotype and paratypes of M. pseudorhenana Ermisch, 1977, and a holotype of M. sajoi Ermisch, 1977. Freshly collected specimens used for the morphological observations were killed using ethylacetate, dissected, and glued on a cardboard mounting card. Specimens used for the molecular analyses were killed and stored in $96 \%$ ethanol. Observations were made using a Leica MZ16 stereomicroscope (Leica Microsystems) with magnification up to $120 \times$, illuminated with diffuse light (neon bulb, $6400 \mathrm{~K}$; Philips, Amsterdam, The Netherlands). Dry specimens were soaked in water with a small amount of acetic acid. Dissected body parts used for drawings were treated with lactic acid for several days, then washed in water or dehydrated in ethanol and mounted on slides in Berlese's fluid (Swan 1936) or Euparal (Paradox Co., Cracow, Poland). Drawings were made using a Leica drawing tube attached to a Leica DM 1000 microscope (Leica Microsystems), then scanned and traced in Adobe Illustrator CC (Adobe, San Jose, California, United States of America). All dissected body parts were glued with 5,5-dimethyl hydantoin formaldehyde on the same card as the respective specimen or put in the microvials filled with glycerine and pinned under the specimen. Digital photographs were made using a Canon EOS 5D mark II camera (Canon, Tokyo, Japan) attached to Zeiss Axio Zoom.V16 stereoscope (Carl Zeiss AG, Oberkochen, Germany). Image stacks were produced manually, combined using the Zerene Stacker 1.4 software (Zerene Systems LLC, Richland, Washington, United States of America), and edited in Adobe Photoshop CC (Adobe). Measurements were taken using a calibrated eyepiece graticule. Morphometric parameters are provided as range and mean \pm standard deviation. The following abbreviations are used for the measured characters: $\mathrm{BL}$ - body length from anterior margin of pronotum to elytral apices along midline; HL - head length from anterior margin of clypeus to occipital margin along midline; HW - maximum head width; PL - pronotal length along midline; PW - maximum pronotal width; EL - elytral length from apex of scutellar shield to apices of elytra along suture; EW maximum elytral width combined; $\mathrm{PyL}$ - maximum length of pygidium; RPL - maximum length of right paramere; LPL - maximum length of left paramere. Terminology used in morphological descriptions follows Franciscolo (1957), Lu et al. (1997), and Lawrence and Ślipiński (2010). All nomenclatorial acts follow regulations of the International Code of Zoological Nomenclature 
(International Trust of Zoological Nomenclature 1999). The examined material is deposited in the following collections: Dávid Selnekovič collection, Bratislava, Slovakia (DSBS), Hungarian Natural History Museum, Budapest, Hungary (HNHM), the Museum für Naturkunde, HumboldtUniversität zu Berlin, Berlin, Germany (MNHU), the Museo Zoologico dell'Università Federico II, Naples, Italy (MZFN), and Senckenberg Deutsches Entomologisches Institut, Müncheberg, Germany (SDEI).

Principal component analysis was performed using PAST 3.12 software (Hammer et al. 2001), using log-transformed variables of three morphometric characters: elytral length, right paramere length, and left paramere length (Supplementary material, Table S1). The dataset consisted of 60 male specimens of $M$. pseudorhenana from Bulgaria, Cyprus, Hungary, Israel, Italy, Montenegro, Slovakia, and Turkey, including holotype and all male genetic vouchers. Plots were subsequently edited in Adobe Illustrator CC.

A total of 30 adults were used for the DNA analyses (Table 3). Genomic DNA was extracted from whole individuals using E.Z.N.A. ${ }^{\bullet}$ Tissue DNA kit (OMEGA Bio-tek Inc., Norcross, Georgia, United States of America) according to the manufacturer's protocol. Extracted and purified DNA is stored at $-25^{\circ} \mathrm{C}$ at the Department of Zoology of Faculty of Natural Sciences, Comenius University, Bratislava, Slovakia. A 568-bp-long fragment of cytochrome oxidase subunit 1 (CO1) was amplified with primers LCO1490 and HCO2198 (Folmer et al. 1994). Standard polymerase chain reaction was performed using DreamTaq ${ }^{\text {Tm }}$ Green DNA Polymerase (Thermo Fisher Scientific Inc., Waltham, Massachusetts, United States of America) for a total volume of $25.0 \mu \mathrm{L}$, comprising 100-200 ng genomic DNA, $2.5 \mu \mathrm{L}$ DreamTaq ${ }^{\text {TM }}$ Buffer, $2.5 \mu \mathrm{L} 25 \mathrm{mM} \mathrm{MgCl}_{2}, 2.0 \mu \mathrm{L}$ of dNTP (deoxynucleotide triphosphohydrolase) mix, $1.0 \mu \mathrm{L}$ of $3.0 \mathrm{pmol} / \mathrm{mL}$ each primer, $0.4 \mu \mathrm{L}(5 \mathrm{U} / \mu \mathrm{L})$ DreamTaq ${ }^{\mathrm{Tm}}$ DNA polymerase and nuclease-free water to $25.0 \mu \mathrm{L}$. Polymerase chain reaction was carried out on an Eppendorf thermal cycler (Eppendorf, Hamburg, Germany), with initial denaturation at $94^{\circ} \mathrm{C}$ for 1 minute, followed by 35 cycles of $94{ }^{\circ} \mathrm{C}$ for 30 seconds, $52^{\circ} \mathrm{C}$ for 40 seconds, and $72{ }^{\circ} \mathrm{C}$ for 1 minute, and 10 minutes of final extension at $72{ }^{\circ} \mathrm{C}$. All polymerase chain reaction products were detected on $1 \%$ agarose gel stained with GoldView (SBS Genetech, Beijing, China). Purification and Sanger sequencing were done in the commercial laboratory of Macrogen Europe Inc. (Amsterdam, The Netherlands) using both amplification primers. Consensus sequences, alignment, and final matrix were produced in Geneious 6.1.8 software (Kearse et al. 2012). Mordella aculeata Linnaeus, 1758 and Mordellistena variegata (Fabricius, 1798) were used as outgroups. Estimates of evolutionary divergence between $\mathrm{CO} 1$ sequences were calculated using the Kimura two-parameter model (Kimura 1980). The dendrogram was based on the maximum likelihood method, and bootstrap support values were calculated in MEGA X software (Kumar et al. 2018). The best-fitted substitution model $($ GTR + I + G) was selected by jModelTest 2 (Darriba et al. 2012) using 1000 replicates. Voucher identifiers and GenBank and BOLD accession numbers are listed in Table 3.

\section{Results}

\section{Morphology and systematics}

Examination of the male lectotype of Mordellistena minima Costa, 1854 deposited in the Museo Zoologico dell'Università Federico II revealed a unique set of characters separating the species from other congeners (see differential diagnosis). The presence of yellow metatibial spurs, in combination with an entirely black body and short antennomeres, observed in the lectotype of M. minima is a rather unique condition that appears only in two other taxa from the M. confinis group: M. emeryi Schilsky, 1895 and M. lindbergi Ermisch, 1963. Re-examination of the lectotype of M. emeryi and comparison of the male genitalia with the lectotype of M. minima (Fig. 5F,G) revealed that the specimens are conspecific, and therefore we propose $M$. emeryi as a new junior 


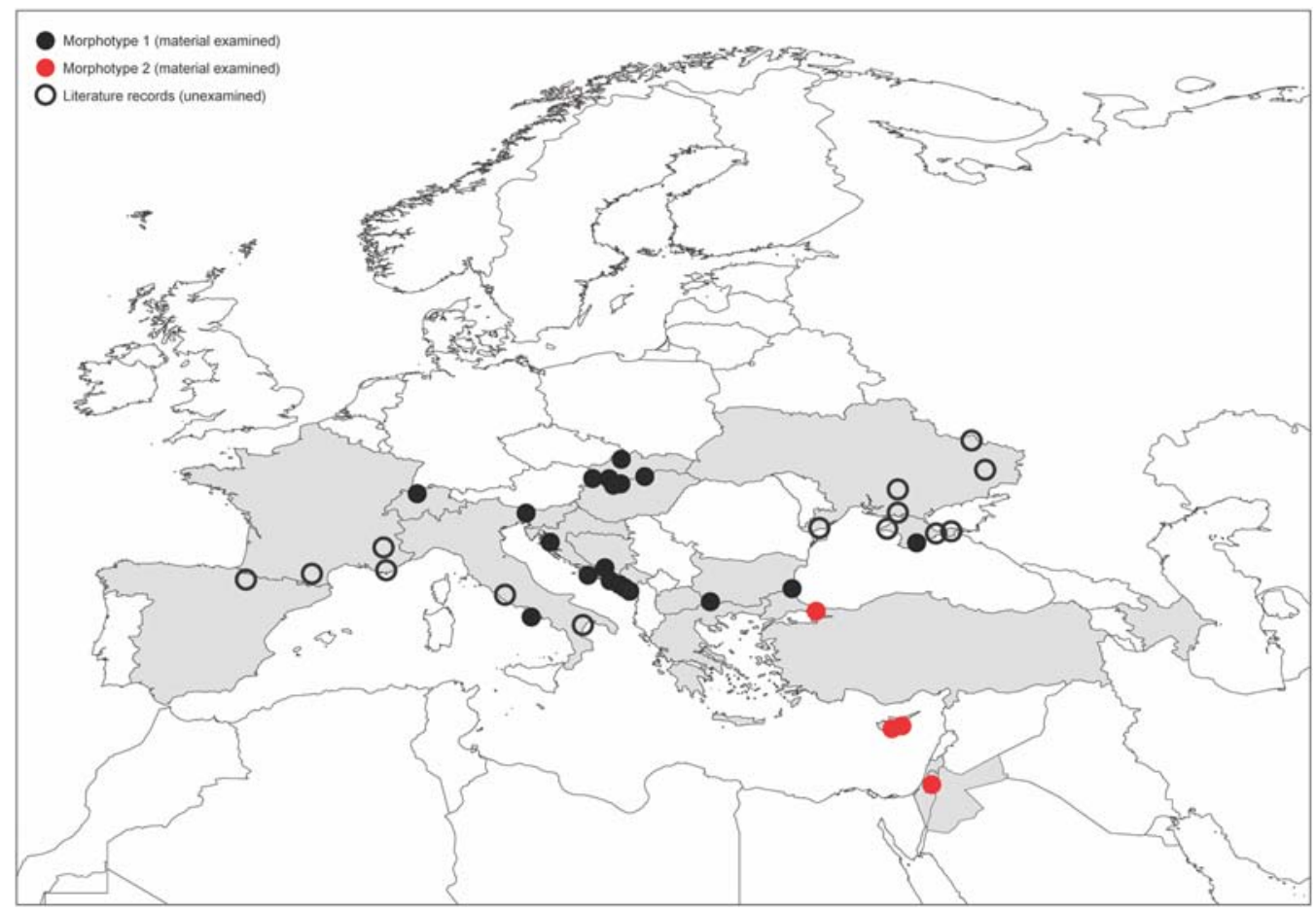

Fig. 2. Distribution of Mordellistena pseudorhenana Ermisch, 1977. Countries with reported occurrence are highlighted in grey. Black-filled circles represent the examined specimens of morphotype 1 , red-filled circles those of morphotype 2 . Black open circles represent the published records that have not been re-examined for the present study.

subjective synonym of the latter. The redescription of the species provided below is based on a lectotype of M. minima, the type series of M. emeryi, and a series of specimens recently collected in the type locality, Ischia, Italy.

The identity of M. minima is not consistent with a previously accepted interpretation of the species presented by Ermisch (1963) and Batten (1977) and followed by subsequent authors (Odnosum 1992, 1993, 2003, 2005, 2010; Horák 2008; Ruzzier 2013). The definition of M. minima as a species, with long apically pointed galea, expanded protibiae in males with distinct clusters of extended setae, and short antennomeres $5-10$, was based on a misidentification. The aforementioned species interpretation was found to correspond with the holotype of M. pseudorhenana Ermisch, 1977 previously synonymised with M. minima by Batten (1980). After a re-examination of the holotype, we consider $M$. pseudorhenana to be a valid species, which can be separated from other members of $M$. confinis species group by the presence of long and pointed galea (Fig. 6A) and the combination of characters listed in the differential diagnosis section. The holotype of M. sajoi Ermisch, 1977 shares the important diagnostic characters with the holotype of $M$. pseudorhenana, and we consider M. sajoi a new junior subjective synonym of the latter species.

Among the material examined for the present study, we were able to identify two morphotypes of M. pseudorhenana that differ in the size and shape of the parameres. Morphotype 1 is represented here by a holotype and 88 additional male specimens from several localities in Europe (Fig. 2), while morphotype 2 is represented by 27 male specimens from Cyprus, Israel, and Turkey. The two morphotypes differ in the size and shape of the parameres: morphotype 1's parameres are shorter and smaller in proportion to the elytral length than they are in morphotype 


\section{A}
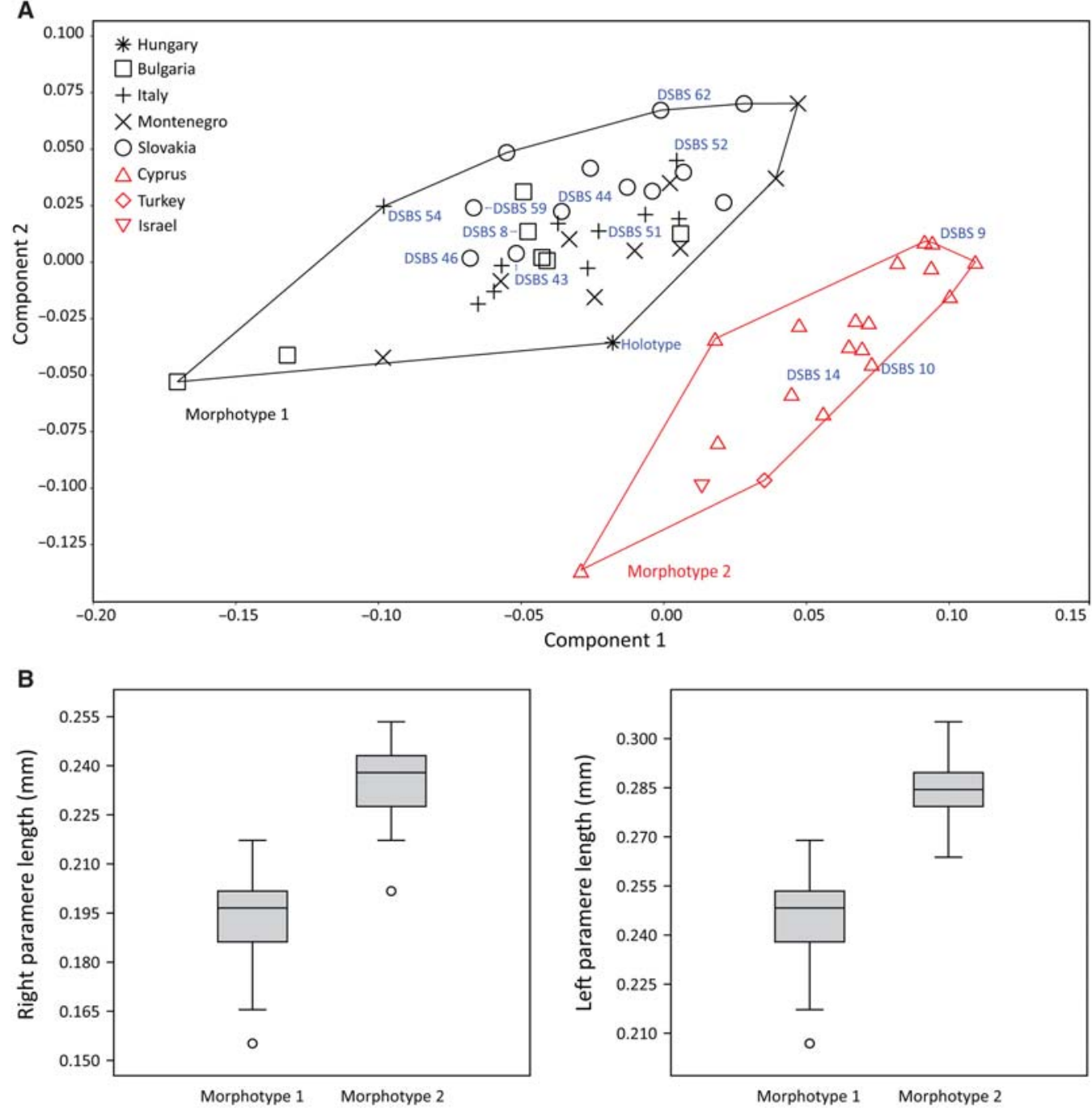

Fig. 3. A, Ordination of 58 male specimens of Mordellistena pseudorhenana Ermisch, 1977 along the first two components of the principal component analysis. The analysis is based on three morphometric characters: elytral length, right paramere length, and left paramere length. The black cluster represents the specimens from central and southern Europe, the red cluster represents specimens from Cyprus. Entire dataset used for the analysis is provided in Supplementary material, Table S1; B, differences in the length of parameres between the specimens of M. pseudorhenana from southern and central Europe versus the specimens from Cyprus.

2 (Figs. 3B, 6E, F; Table 1); basal portions of the parameres in morphotype 1 are shorter in proportion to the distal processes than they are in morphotype 2 (Fig. 6E,F); and the dorsal process of the left paramere in morphotype 1 is shorter and wider than it is in morphotype 2 (Fig. 6E, F). The differences in dimensions are also shown by the results of the principal component analysis (Fig. 3A). Despite the morphological differences, the genetic divergence in CO1 fragment between the representatives of the two morphotypes is very low (Table 5; discussed in the Molecular Analyses section). 
Table 1. Dimensions of parameres in Mordellistena minima Costa, 1854 and two morphotypes of M. pseudorhenana Ermisch, 1977. The ranges are followed by arithmetic mean \pm standard deviation.

\begin{tabular}{lccc}
\hline & & \multicolumn{2}{c}{ Mordellistena pseudorhenana } \\
\cline { 3 - 4 }$N$ & Mordellistena minima & Morphotype 1 & Morphotype 2 \\
\hline \multirow{2}{*}{$N$} & 14 & 39 & 21 \\
\hline $\mathrm{RPL}$ & $0.19-0.27(0.23 \pm 0.02)$ & $0.16-0.22(0.19 \pm 0.01)$ & $0.20-0.25(0.23 \pm 0.01)$ \\
\hdashline $\mathrm{LPL}$ & $0.24-0.30(0.28 \pm 0.02)$ & $0.21-0.27(0.25 \pm 0.01)$ & $0.26-0.31(0.28 \pm 0.01)$ \\
\hdashline EL/RPL & $7.54-9.10(8.30 \pm 0.46)$ & $9.10-12.10(10.48 \pm 0.61)$ & $7.04-8.77(8.14 \pm 0.52)$ \\
\hline EL/LPL & $5.90-7.35(6.73 \pm 0.33)$ & $7.05-9.32(8.24 \pm 0.48)$ & $5.52-7.49(6.73 \pm 0.49)$ \\
\hline
\end{tabular}

EL, elytral length from apex of scutellar shield to apices of elytra along suture; RPL, maximum length of right paramere; LPL, maximum length of left paramere.

Table 2. Principal component loadings and percentage of explained variance from principal component (PC) analysis of 60 male specimens of Mordellistena pseudorhenana Ermisch, 1977. The highest values are highlighted in bold.

\begin{tabular}{|c|c|c|c|}
\hline & PC 1 & PC 2 & PC 3 \\
\hline Explained variance (\%) & 68.45 & 29.84 & 1.71 \\
\hline \multicolumn{4}{|l|}{ Loadings of variables } \\
\hline EL & 0.196 & 0.981 & 0.008 \\
\hline RPL & 0.578 & -0.122 & 0.807 \\
\hline LPL & 0.792 & -0.153 & -0.590 \\
\hline
\end{tabular}

EL, elytral length from apex of scutellar shield to apices of elytra along suture; RPL, maximum length of right paramere; LPL, maximum length of left paramere.

\section{Morphometric analysis}

For the principal component analysis, we focused on two morphotypes of M. pseudorhenana that can be distinguished based on the shape and size of the parameres. The first group representing morphotype 1 consisted of 39 male specimens from Bulgaria, Hungary, Italy, Montenegro, and Slovakia, including the holotype and voucher specimens used for the molecular analyses. The second group consisted of 21 male specimens from Cyprus, Israel, and Turkey, also including the genetic vouchers. The principal component analysis was based on a set of three characters (elytral length, right paramere length, and left paramere length) that best reflect the differences in morphology. The analysis revealed two separate clusters that represent the two morphotypes (Fig. $3 \mathrm{~A}$ ). The first principal component explained $68.5 \%$ of the variance and correlated strongly with the length of the right paramere (Table 2). The second principal component explained $29.8 \%$ of the variance and correlated strongly with elytral length (Table 2). Results of the principal component analysis are congruent with differences in the actual measurements (Fig. 3B; Table 1; Supplementary material, Table S1).

\section{Molecular analyses}

The sequences of $\mathrm{CO} 1$ gene fragment were obtained from 30 out of 35 amplified samples representing five species of $M$. confinis group, plus two outgroup species (Table 3). The analysed CO1 fragment was $568 \mathrm{bp}$ long, with no indels and stop codons. The maximum likelihood analysis revealed all five presumed ingroup species as distinctly separate clades, each with bootstrap value of 100 (Fig. 4). The Kimura two-parameter genetic divergences between species were high and ranged from $13.9 \%$ 
Table 3. Samples used in the molecular analyses with voucher IDs, GenBank, and Barcode of Life Database (BOLD) BIN accession numbers, haplotypes, and countries of origin.

\begin{tabular}{|c|c|c|c|c|c|}
\hline Species & Voucher & GenBank & BOLD BIN & Haplotype & Country \\
\hline Mordellistena pseudorhenana & DSBS 6 & MT232528 & BOLD:AEA3479 & $\mathrm{Ht} \_1$ & Bulgaria \\
\hline Mordellistena pseudorhenana & DSBS 7 & MT232529 & BOLD:AEA3479 & Ht_1 & Bulgaria \\
\hline Mordellistena pseudorhenana & DSBS 8 & MT232530 & BOLD:AEA3479 & Ht_1 & Bulgaria \\
\hline Mordellistena pseudorhenana & DSBS 9 & MT232531 & BOLD:AEA3479 & Ht_2 & Cyprus \\
\hline Mordellistena pseudorhenana & DSBS 12 & MT232533 & BOLD:AEA3479 & $\mathrm{Ht} \_2$ & Cyprus \\
\hline Mordellistena pseudorhenana & DSBS 13 & MT232534 & BOLD:AEA3479 & Ht_2 & Cyprus \\
\hline Mordellistena pseudorhenana & DSBS 10 & MT232532 & BOLD:AEA3479 & Ht_3 & Cyprus \\
\hline Mordellistena pseudorhenana & DSBS 14 & MT232535 & BOLD:AEA3479 & Ht_3 & Cyprus \\
\hline Mordellistena pseudorhenana & DSBS 51 & MT232544 & BOLD:AEA3479 & Ht_4 & Italy \\
\hline Mordellistena pseudorhenana & DSBS 52 & MT232545 & BOLD:AEA3479 & Ht_4 & Italy \\
\hline Mordellistena pseudorhenana & DSBS 53 & MT232546 & BOLD:AEA3479 & Ht_4 & Italy \\
\hline Mordellistena pseudorhenana & DSBS 54 & MT232547 & BOLD:AEA3479 & $\mathrm{Ht} \_4$ & Italy \\
\hline Mordellistena pseudorhenana & DSBS 46 & MT232542 & BOLD:AEA3479 & Ht_5 & Slovakia \\
\hline Mordellistena pseudorhenana & DSBS 43 & MT232539 & BOLD:AEA3479 & Ht_6 & Slovakia \\
\hline Mordellistena pseudorhenana & DSBS 44 & MT232540 & BOLD:AEA3479 & $\mathrm{Ht} \_6$ & Slovakia \\
\hline Mordellistena pseudorhenana & DSBS 45 & MT232541 & BOLD:AEA3479 & $\mathrm{Ht} \_6$ & Slovakia \\
\hline Mordellistena pseudorhenana & DSBS 59 & MT232548 & BOLD:AEA3479 & Ht_6 & Slovakia \\
\hline Mordellistena pseudorhenana & DSBS 62 & MT232549 & BOLD:AEA3479 & Ht_6 & Slovakia \\
\hline Mordellistena minima & DSBS 79 & MT232550 & BOLD:AED6814 & Ht_7 & Italy \\
\hline Mordellistena minima & DSBS 81 & MT232551 & BOLD:AED6814 & $\mathrm{Ht} \_7$ & Italy \\
\hline Mordellistena lindbergi & DSBS 86 & MT232553 & BOLD:AED2412 & Ht_8 & Spain \\
\hline Mordellistena hirtipes & DSBS 18 & MT232537 & BOLD:AED9694 & Ht_9 & Cyprus \\
\hline Mordellistena hirtipes & DSBS 17 & MT232536 & BOLD:AED9694 & $\mathrm{Ht} \_10$ & Cyprus \\
\hline Mordellistena hirtipes & DSBS 19 & MT232538 & BOLD:AED9694 & $\mathrm{Ht} \_10$ & Cyprus \\
\hline Mordellistena hirtipes & DSBS 50 & MT232543 & BOLD:AED9695 & $\mathrm{Ht} \_11$ & Italy \\
\hline Mordellistena purpurascens & DSBS 82 & MT232552 & BOLD:AED6443 & $\mathrm{Ht} \_12$ & Italy \\
\hline Mordellistena purpurascens & DSBS 117 & MT232555 & BOLD:AED6443 & $\mathrm{Ht} \_12$ & Italy \\
\hline Mordellistena purpurascens & DSBS 111 & MT232554 & BOLD:AED6443 & $\mathrm{Ht}_{2} 13$ & Spain \\
\hline \multicolumn{6}{|l|}{ Outgroup } \\
\hline Mordella aculeata & DSBS 78 & MT232556 & BOLD:AED3319 & $\mathrm{Ht} \_14$ & Slovakia \\
\hline Mordellistena variegata & DSBS 89 & MT232557 & BOLD:ADW7498 & $\mathrm{Ht} \_15$ & Germany \\
\hline
\end{tabular}

DSBS, Dávid Selnekovič collection, Bratislava, Slovakia.

between M. hirtipes Schilsky, 1895 and M. purpurascens Costa, 1854 to $22.4 \%$ between M. minima and M. hirtipes (Table 4; Supplementary material, Table S2). The mean interspecific distance between the five analysed species from the M. confinis species group was $18.5 \%$. The mean intraspecific distances ranged from $0 \%$ in M. minima to $1.9 \%$ in $M$. hirtipes (Table 4). 
Table 4. Pairwise genetic distances between and within five species of the Mordellistena confinis Costa, 1854 species group, plus two outgroup species, based on 568-bp fragment of the $\mathrm{CO} 1$ mitochondrial gene calculated by the Kimura 2-parameter model. The intraspecific divergences are highlighted in bold.

\begin{tabular}{|c|c|c|c|c|c|c|c|}
\hline & 1. & 2. & 3. & 4. & 5. & 6. & 7. \\
\hline 1. Mordellistena pseudorhenana & 0.0066 & & & & & & \\
\hline 2. Mordellistena hirtipes & 0.1764 & 0.0192 & & & & & \\
\hline 3. Mordellistena minima & 0.1999 & 0.2244 & 0.0000 & & & & \\
\hline 4. Mordellistena purpurascens & 0.1944 & 0.1386 & 0.2177 & 0.0035 & & & \\
\hline 5. Mordellistena lindbergi & 0.1670 & 0.1498 & 0.1929 & 0.1884 & n/a & & \\
\hline 6. Mordella aculeata & 0.2836 & 0.2907 & 0.3101 & 0.3406 & 0.3260 & n/a & \\
\hline 7. Mordellistena variegata & 0.3154 & 0.2938 & 0.2198 & 0.3185 & 0.3077 & 0.3120 & n/a \\
\hline
\end{tabular}

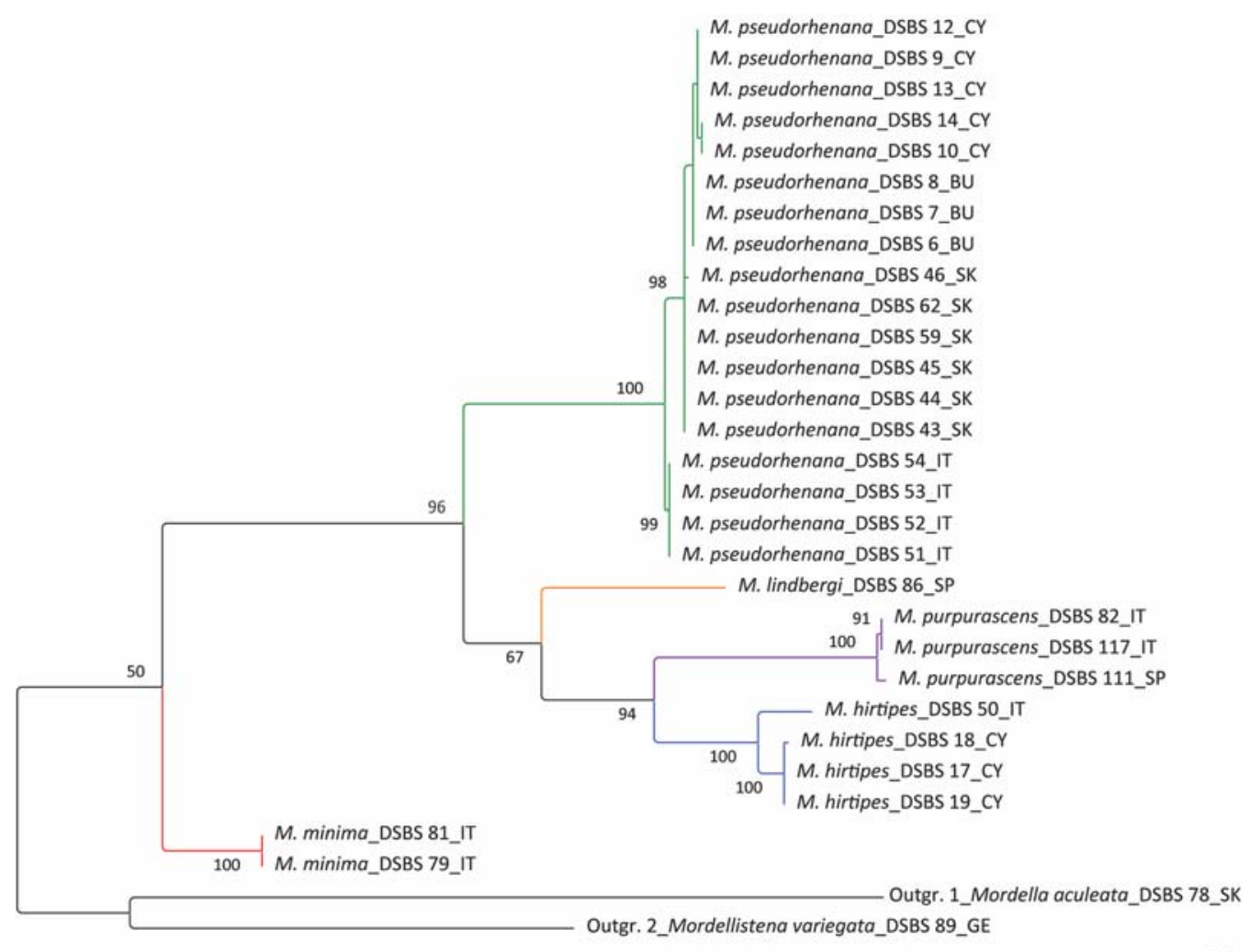

Fig. 4. Maximum likelihood tree based on 568-bp fragment of $\mathrm{CO} 1$ mitochondrial gene sampled from five species of Mordellistena confinis Costa, 1854 species group.

The M. pseudorhenana morphotype 1 was represented in the analyses by 13 specimens from Bulgaria, Italy, and Slovakia. Morphotype 2 was represented by five specimens from Cyprus. The analyses revealed four haplotypes in the morphotype 1 and two haplotypes in morphotype 2 (Tables 3 and 5). Based on the Kimura two-parameter distances, M. lindbergi was recovered as the closest neighbour of M. pseudorhenana, with the smallest interspecific distance (16.5\%) 
Table 5. Pairwise genetic distances between detected haplotypes of Mordellistena pseudorhenana Ermisch, 1977, based on a 568-bp fragment of $\mathrm{CO}$ gene calculated by the Kimura 2-parameter model.

\begin{tabular}{|c|c|c|c|c|c|}
\hline Haplotype & 1. & 2. & 3. & 4. & 5. \\
\hline \multicolumn{6}{|l|}{ 1. Ht_1 (Bulgaria) } \\
\hline 2. Ht_2 (Cyprus) & 0.0018 & & & & \\
\hline 3. Ht_3 (Cyprus) & 0.0035 & 0.0018 & & & \\
\hline 4. Ht_6 (Slovakia) & 0.0035 & 0.0053 & 0.0071 & & \\
\hline 5. Ht_5 (Slovakia) & 0.0053 & 0.0071 & 0.0089 & 0.0018 & \\
\hline 6. Ht_4 (Italy) & 0.0142 & 0.0125 & 0.0143 & 0.0107 & 0.0125 \\
\hline
\end{tabular}

(Supplementary material, Table S2). The divergences between the two M. pseudorhenana morphotypes ranged from $0.2 \%$ between haplotypes from Cyprus and Bulgaria to $1.4 \%$ between haplotype 3 from Cyprus and haplotype 4 from Italy (Table 5). The highest intraspecific Kimura two-parameter distance between the two morphotypes is 11.8 times less than the smallest interspecific distance between $M$. pseudorhenana and M. lindbergi. The analysed CO1 fragment did not provide any evidence to consider the two morphotypes separate species.

\section{Distribution}

Distributional records for M. minima that were published by Ermisch (1963), Batten (1976), Odnosum (1993, 2003, 2010), and Horák (2008, 2020) were identified to refer to M. pseudorhenana, based on the revised material and the illustrations of male genitalia presented in the publications. The large series of examined material revealed new distributional records for M. pseudorhenana from Bosnia and Herzegovina, Slovenia, and Switzerland. The range of M. pseudorhenana reaches from Spain in the west, across the whole Mediterranean basin to Turkey, from Israel and Jordan in the south, across the Pannonian basin to Hungary and Slovakia in the north, and along the Black and Caspian seas to Ukraine, Azerbaijan, and Kyrgyzstan in the east (Fig. 2). A new record from Rajecké Teplice, Slovakia marks the northernmost known extent of the species' distribution (Fig. 2).

\section{Mordellistena (s. str.) minima Costa, 1854}

(Figs. 1A, 2, 4, 5, 7A)

Mordellistena (s. str.) minima Costa, 1854: 18-19, Pl. XXII, Fig. 1 [original description, figures, type locality: Ischia, Italy]; Mulsant (1856: 383-385) [description]; Gemminger and Harold (1870: 2112) [catalogue, first report from France].

Mordellistena (s. str.) micans: Emery (1876: 96) [as syn. of M. micans]; Heyden et al. (1883: 142) [catalogue, as var. of M. micans]; Heyden et al. (1906: 456) [catalogue, as syn. of M. micans]; Winkler (1928: 885) [catalogue, as syn. of M. micans].

Mordellistena (s. str.) confinis var. emeryi Schilsky, 1895: 53 new synonymy [original description, type locality: Oesterreich [Austria]]; Heyden et al. (1906: 456) [catalogue]; Schaufuss (1916: 766) [catalogue, first report from Germany]; Roubal (1934: 5) [first report from Morocco]; Franciscolo (1942: 7) [localities], Franciscolo (1956: 4) [localities].

Mordellistena (s. str.) emeryi: Ermisch (1956: 286, 308-309) [new status, key, first report from Albania, Algeria, Croatia, Spain, Switzerland]; Ermisch (1969a: 847, 853) [localities]; Ermisch (1969b: 181) [key]; Köstlin and Vogt (1971: 51) [localities]; Batten (1976: 167) [localities]; Ermisch (1977: 167) [localities]; Kaszab (1979: 69-70) [key, figures]; Compte (1985: 66) [localities]; Angelini (1986: 87) [localities]; Franciscolo (1991: 168) [localities, first report from Tunisia]; 
Horák (1996: 178) [key]; Horák (2008: 97) [catalogue, first report from Greece]; Ruzzier (2013: 107) [localities]; Horák (2020: 93) [catalogue].

Type locality. Ischia, Italy.

Type material examined. Lectotype of M. minima (Fig. $5 \mathrm{~A}, \mathrm{~F}$ ) by designation of Selnekovič and Improta (2020), male, MZFN, labelled: "45.194 | Mordellistena minima, n. Ischia [original Costa's label] | LECTOTYPUS Mordellistena minima Costa, 1854 D. Selnekovič des. 2019 [red label]"; in bad condition, pinned between elytra, right antenna, right maxillary palpus, and left metatarsus missing; left antenna, left maxilla, left elytron, abdomen, and genitalia stored in microvial with glycerine. Lectotype of $\boldsymbol{M}$. emeryi by present designation (Fig. 5G), MNHU, male, labelled: "Austria Schuster [handwritten] | ô | Type [red label] | Zool. Mus. Berlin | [card with dissected genitalia] | LECTOTYPUS Mordellistena (s. str.) emeryi Schilsky J. Horák design. 2006 [red label]". Paralectotypes of $\boldsymbol{M}$. emeryi by present designation, MNHU, 5 males, 4 females, 2 sex undetermined, labelled: "Austria Schuster [handwritten] | Type [red label] | Zool. Mus. Berlin | PARALECTOTYPUS Mordellistena (s. str.) emeryi Schilsky J. Horák design. 2006 [red label]”.

Additional material examined. Italy: $90^{\star} \delta^{\circ}, 3$ 우, Ischia Island, Serrara env., $40^{\circ} 43^{\prime} 17^{\prime \prime} \mathrm{N}$, $13^{\circ} 52^{\prime} 59^{\prime \prime}$ E, 550 m a.s.l., 30.vi.2019, D. Selnekovič leg., dry grassland (DSBS DSBS_79, DSBS_81, DS-138 to DS-140, DS-154 to DS-158); 10 ఫొరో, 7 우, Ischia Island, Serrara env., $40^{\circ} 42^{\prime} 60^{\prime \prime} \mathrm{N}$, $13^{\circ} 53^{\prime} 11^{\prime \prime}$ E, $517 \mathrm{~m}$ a.s.l., 29.vi.2019, D. Selnekovič leg., ruderal vegetation, on flowers of Daucus (DSBS DS-141 to DS-147, DS-151 to DS-153, DS-159 to DS-168).

Differential diagnosis. The species is characterised by the following combination of characters: (1) body black, metatibial spurs yellowish (Fig. 1A); (2) pubescence on most body surfaces yellowish to light-brownish with purple sheen; (3) antennomeres 5-10 ca. 1.20-1.30 times longer than wide; (4) galea short, apically rounded (Fig. 5A); (5) protibiae in males slightly expanded, sometimes with several extended setae; (6) metatibiae with 3-5 short lateral ridges, metatarsomere 1 with 3-5 ridges, metatarsomere 2 with two ridges; (7) abdominal sternite VIII in males ca. 2.00 times longer than wide, rounded at apex (Fig. 5C); in females ca. 1.60 times longer than wide, with speculum ventrale narrowly clavate (Fig. 5D); and (8) parameres as in Figure 5F,G; ovipositor rather short, with paraprocts distinctly shorter than gonocoxites, as in Figure 5E.

Mordellistena minima may be assigned to the $M$. confinis species group as defined by Ermisch (1956). Within this group, the combination of yellowish metatibial spurs and completely black body, including legs and antennae, is shared by three other species: M. lindbergi Ermisch, 1963, M. eversi Ermisch, 1965, and M. canariensis Ermisch, 1965. The species most closely resembles $M$. lindbergi and can be distinguished by the following characters: (1) the pubescence on elytra in M. minima has a distinct purple sheen, whereas that of $M$. lindbergi has a distinct greenish sheen; (2) protibiae are, in males of $M$. minima, slightly expanded, sometimes with several extended setae, compared to those of $M$. lindbergi, which are not expanded and are without extended setae; (3) the metatibiae in M. minima usually possess 4-5 lateral ridges, whereas those of $M$. lindbergi usually possess three lateral ridges, the last of which is very short; (4) abdominal sternite VIII in males of M. minima is ca. 2.00 times longer than wide with a rounded apex (Fig. 5C), whereas that of $M$. lindbergi is approximately 1.60 times longer than wide, with lateral margins distinctly convergent and a slightly emarginated apex; (5) the parameres of M. minima are as illustrated in Figure 5F,G, and those of M. lindbergi are as shown in Horák (1996); (6) the species are separated by ca. 19\% divergence in the barcoding fragment of the CO1 gene (Table 3). Both $M$. eversi and $M$. canariensis are known only from the Canary Islands and differ from M. minima by having distinctly longer antennae, with antennomeres 5-10 almost twice as long as wide.

Redescription. Body slender (Fig. 1A), wedge-shaped, widest before middle of elytra, dorsum moderately convex, venter strongly so. Basic metric characters are listed in Tables 1 and 6 . Colour of almost entire integument black, with very fine bluish sheen; maxillary palpi and four basal antennomeres sometimes dark reddish-brown; metatibial spurs yellowish with black apices. Vestiture consisting of dense, decumbent, dorso-ventrally flattened setae; colour uniformly 


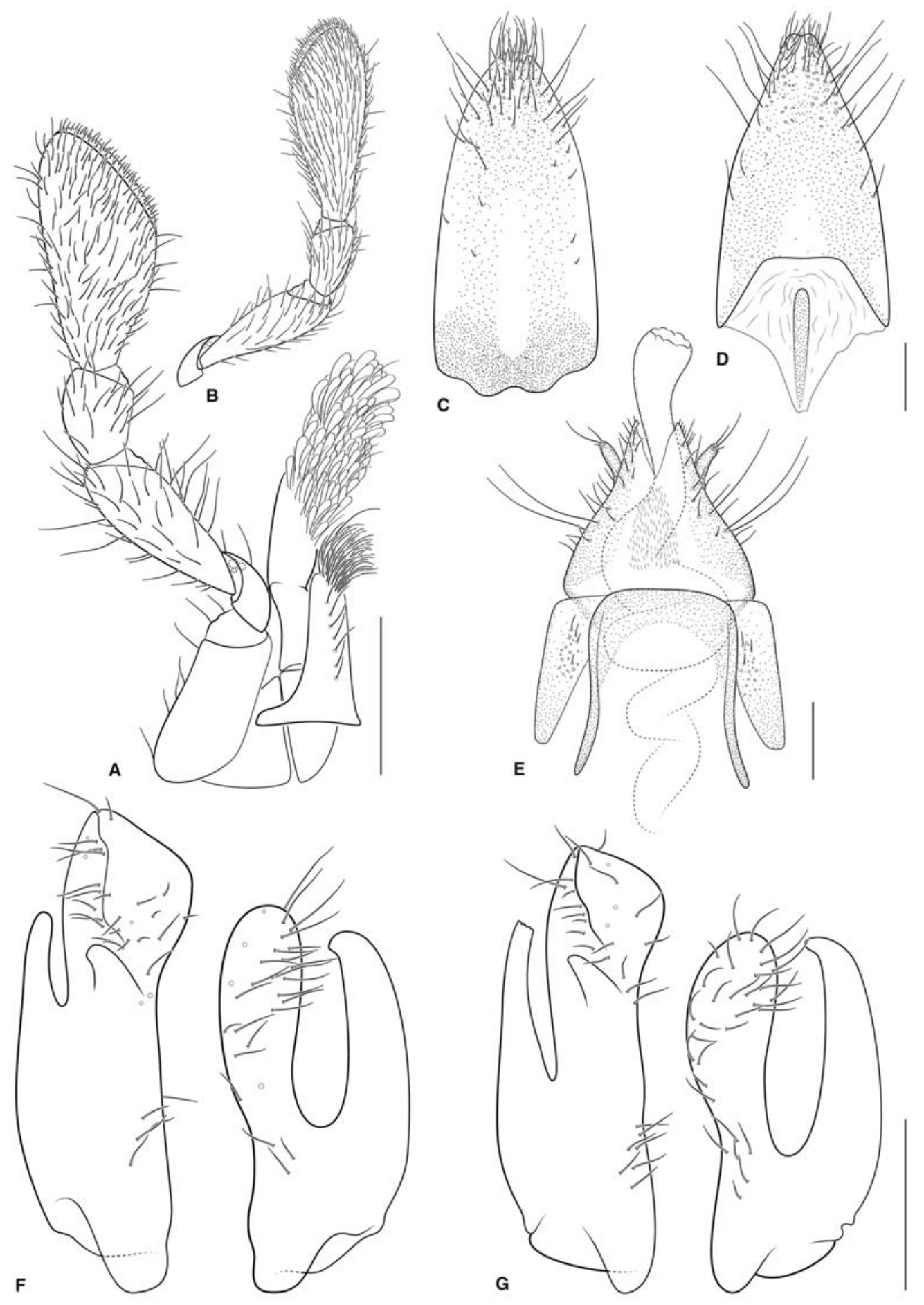

Fig. 5. Mordellistena minima Costa, 1854. A, male maxilla (lectotype); B, female maxillary palp; C, male abdominal sternite VIII; D, female abdominal sternite VIII; E, ovipositor; F, parameres (lectotype); and G, parameres (M. emeryi Schilsky, 1895 lectotype). 
yellowish on head and sternal thoracic parts; in anterior portions of pronotum yellowish, somewhat darkened posteriorly; in anterior portions of elytra yellowish, gradually darkened posteriorly to completely black at apices; on first to abdominal ventrites yellowish, on following ventrites gradually darkened to completely black on ventrite 5 and pygidium; on legs yellowish, somewhat darkened towards apices; vestiture on pronotum and elytra with distinct purple sheen.

Head on dorsum moderately convex; surface finely microreticulated with minute, round, setiferous punctures; frontoclypeus with anterior margin straight; occipital carina evenly rounded in dorsal aspect, straight to slightly concave in posterior aspect; tempora absent. Labrum with antero-lateral angles broadly rounded, transverse with exposed portion $c a$. 1.30 times wider than long, microreticulate, bearing setiferous punctures. Eyes broadly oval, ca. 1.30 times longer than wide, finely faceted with distinct interfacetal setae. Antennae moderately long, feebly serrate (Fig. 1A); scapus and pedicel cylindrical, subequal; antennomeres 3-4 subequal, slightly shorter than pedicel, distinctly shorter than following segments; antennomeres 5-10 subequal, in males ca. 1.30 times and in females $c a$. 1.20 times longer than wide; antennomere 11 elongate oval, ca. 2.00 times longer than wide. Mandibles slightly asymmetrical in molar parts, bidentate, with exposed lateral portion setose; mola denticulate; prostheca with thin, medially oriented trichoid sensilla. Maxilla as in Figure 5 A,B, galea distinctly shorter than maxillary palpus, rounded or subtruncate at apex, densely covered with trichoid and apically widened, spoon-like sensilla; lacinia with trichoid sensilla arranged in longitudinal row and scattered in apical portion; palpifer cylindrical, setose laterally; maxillary palpomere 1 short, setose ventrally; palpomere 2 moderately widened apically, in males not expanded and with few extended setae; palpomere $3 \mathrm{ca}$. 0.50 times as long as previous one; terminal palpomere narrowly securiform, ca. 2.50 times longer than wide, with inner angle situated behind middle. Terminal labial palpomere broadly fusiform.

Pronotum moderately convex, slightly wider than long (Table 6), widest behind middle, finely microreticulate with dense rasp-like punctures; anterior margin slightly produced in middle, margination complete, anterior angles rounded; lateral carinae rounded in dorsal aspect and very slightly concave in lateral aspect, margination inapparent but complete; posterior angles obtuse and rounded in lateral aspect. Prosternal process obliterated. Scutellar shield triangular, with rasplike setiferous punctures. Mesoventral process truncate at apex, as wide as mesotibia. Metaventral discrimen distinct, reaching shortly before middle. Metanepisternite rather wide, with lateral margin concave and mesal margin straight.

Elytra moderately convex, about twice as long as combined width (Table 6), widest around end of anterior one-third, moderately narrowed, with lateral carinae convergent behind middle (Fig. 1A); apices separately rounded; surface with rasp-like, setiferous punctures, and with fine microreticulation consisting of transverse, undulate lines.

Protibiae straight, in males expanded basally and sometimes with few extended setae; mesotibiae slightly bent medially; metatibiae with short apical ridge and 3-5 short lateral ridges parallel to apical tibial margin, reaching $c a$. one-quarter of tibial width, subequal in length except the last one usually shorter, sometimes inapparent; metatibial spurs yellowish with black apices, outer one ca. 0.60 times as long as inner one. Protarsi slightly longer than protibiae, first protarsomere slightly longer than following two segments combined, penultimate protarsomere distinctly longer than wide, with anterior margin slightly concave, claws tridentate; mesotarsi $c a$. 1.30 times as long as mesotibiae; metatarsomere 1 with 3-5 ridges, metatarsomere 2 with two ridges, metatarsomere 3 without ridges.

Pygidium moderately long, conical, narrowly truncate at apex (Fig. 1A), about half as long as elytra (Table 6) and about twice as long as ventrite 5 . Ventrite 5 with apical margin convex. Sternite VIII in males ca. twice as long as wide, setose apically, with lateral margins convergent and evenly rounded, apex rounded (Fig. 5C); in females ca. 1.60 times longer than wide, setose apico-laterally, with apex shallowly concave, spiculum ventrale narrowly clavate (Fig. 5D). Sternite IX in males slender, arrow shaped. Phallobase moderately long, ca. 0.40 times as long as elytra, with distal arms ca. 2.80 times as long as tubular part. Median lobe long and slender, almost as 
Table 6. Metric characters of Mordellistena minima Costa, 1854 and M. pseudorhenana Ermisch, 1977. Measurements are provided as range followed by mean \pm standard deviation.

\begin{tabular}{|c|c|c|c|c|}
\hline & \multicolumn{2}{|c|}{ Mordellistena minima } & \multicolumn{2}{|c|}{ Mordellistena pseudorhenana } \\
\hline & Males & Females & Males & Females \\
\hline$N$ & 14 & 7 & 20 & 20 \\
\hline $\mathrm{BL}(\mathrm{mm})$ & $\begin{array}{c}1.82-2.73 \\
2.44 \pm 0.26\end{array}$ & $\begin{array}{c}2.60-3.19 \\
2.84 \pm 0.23\end{array}$ & $\begin{array}{c}1.89-2.99 \\
2.58 \pm 0.32\end{array}$ & $\begin{array}{c}2.24-3.45 \\
2.76 \pm 0.37\end{array}$ \\
\hline $\mathrm{HL}(\mathrm{mm})$ & $\begin{array}{c}0.44-0.65 \\
0.59 \pm 0.05\end{array}$ & $\begin{array}{c}0.60-0.75 \\
0.68 \pm 0.05\end{array}$ & $\begin{array}{c}0.51-0.73 \\
0.64 \pm 0.06\end{array}$ & $\begin{array}{c}0.56-0.84 \\
0.68 \pm 0.08\end{array}$ \\
\hline $\mathrm{HW}(\mathrm{mm})$ & $\begin{array}{c}0.48-0.75 \\
0.68 \pm 0.07\end{array}$ & $\begin{array}{c}0.70-0.82 \\
0.76 \pm 0.04\end{array}$ & $\begin{array}{c}0.53-0.82 \\
0.70 \pm 0.08\end{array}$ & $\begin{array}{c}0.59-0.91 \\
0.74 \pm 0.09\end{array}$ \\
\hline $\mathrm{HW} / \mathrm{HL}$ & $\begin{array}{c}1.08-1.20 \\
1.14 \pm 0.04\end{array}$ & $\begin{array}{c}1.07-1.17 \\
1.11 \pm 0.03\end{array}$ & $\begin{array}{c}1.04-1.17 \\
1.09 \pm 0.03\end{array}$ & $\begin{array}{c}1.04-1.16 \\
1.09 \pm 0.03\end{array}$ \\
\hline $\mathrm{PL}(\mathrm{mm})$ & $\begin{array}{c}0.52-0.84 \\
0.75 \pm 0.08\end{array}$ & $\begin{array}{c}0.81-0.96 \\
0.88 \pm 0.06\end{array}$ & $\begin{array}{c}0.58-0.93 \\
0.78 \pm 0.11\end{array}$ & $\begin{array}{c}0.70-1.11 \\
0.87 \pm 0.13\end{array}$ \\
\hline PW (mm) & $\begin{array}{c}0.57-0.98 \\
0.83 \pm 0.09\end{array}$ & $\begin{array}{c}0.91-1.12 \\
1.01 \pm 0.07\end{array}$ & $\begin{array}{c}0.60-0.99 \\
0.82 \pm 0.11\end{array}$ & $\begin{array}{c}0.73-1.16 \\
0.91 \pm 0.14\end{array}$ \\
\hline PW/PL & $\begin{array}{c}1.05-1.16 \\
1.11 \pm 0.03\end{array}$ & $\begin{array}{c}1.11-1.18 \\
1.15 \pm 0.02\end{array}$ & $\begin{array}{c}1.00-1.09 \\
1.05 \pm 0.02\end{array}$ & $\begin{array}{c}1.00-1.14 \\
1.05 \pm 0.04\end{array}$ \\
\hline $\mathrm{EL}(\mathrm{mm})$ & $\begin{array}{c}1.40-2.08 \\
1.89 \pm 0.18\end{array}$ & $\begin{array}{c}1.98-2.42 \\
2.16 \pm 0.17\end{array}$ & $\begin{array}{c}1.50-2.32 \\
2.02 \pm 0.24\end{array}$ & $\begin{array}{c}1.73-2.68 \\
2.16 \pm 0.27\end{array}$ \\
\hline $\mathrm{EW}(\mathrm{mm})$ & $\begin{array}{c}0.64-1.01 \\
0.89 \pm 0.09\end{array}$ & $\begin{array}{c}0.94-1.20 \\
1.06 \pm 0.09\end{array}$ & $\begin{array}{c}0.67-1.05 \\
0.88 \pm 0.11\end{array}$ & $\begin{array}{c}0.82-1.23 \\
1.00 \pm 0.14\end{array}$ \\
\hline $\mathrm{EL} / \mathrm{EW}$ & $\begin{array}{c}2.03-2.31 \\
2.13 \pm 0.08\end{array}$ & $\begin{array}{c}1.98-2.11 \\
2.03 \pm 0.04\end{array}$ & $\begin{array}{c}2.13-2.59 \\
2.30 \pm 0.10\end{array}$ & $\begin{array}{c}2.02-2.27 \\
2.15 \pm 0.08\end{array}$ \\
\hline PyL (mm) & $\begin{array}{c}0.78-1.18 \\
1.05 \pm 0.10\end{array}$ & $\begin{array}{c}1.00-1.17 \\
1.07 \pm 0.05\end{array}$ & $\begin{array}{c}0.82-1.48 \\
1.20 \pm 0.17\end{array}$ & $\begin{array}{c}0.84-1.50 \\
1.18 \pm 0.16\end{array}$ \\
\hline EL/PyL & $\begin{array}{c}1.66-1.98 \\
1.80 \pm 0.07\end{array}$ & $\begin{array}{c}1.88-2.25 \\
2.01 \pm 0.12\end{array}$ & $\begin{array}{c}1.52-2.00 \\
1.70 \pm 0.13\end{array}$ & $\begin{array}{c}1.65-2.16 \\
1.83 \pm 0.13\end{array}$ \\
\hline
\end{tabular}

$\mathrm{BL}$, body length from anterior margin of pronotum to elytral apices along midline; HL, head length from anterior margin of clypeus to occipital margin along midline; HW, maximum head width; PL, pronotal length along midline; PW, maximum pronotal width; EL, elytral length from apex of scutellar shield to apices of elytra along suture; EW, maximum elytral width combined; PyL, maximum length of pygidium; $\mathrm{RPL}$, maximum length of right paramere; LPL, maximum length of left paramere.

long as elytra, with apex slightly expanded and pointed. Dimensions of parameres are provided in Table 1. Right paramere (Fig. 5F,G) with basal part distinctly shorter than distal processes; ventral process subequal in length to dorsal process and curved dorsally with pointed apex; dorsal process rather narrow, expanded, and rounded apically, setose. Left paramere (Fig. 5F,G) with basal part slightly shorter to slightly longer than dorsal process and setose dorso-medially; ventral process narrowly rounded at apex; dorsal process wide, obliquely truncate, and setose apically; medial process small. Ovipositor short and wide (Fig. 5E), slightly sclerotised except for baculi; paraprocts distinctly shorter than gonocoxites, with heavily sclerotised baculi and several trichoid sensilla dorsolaterally; proctiger short, truncate at apex, with sclerotised baculi; gonocoxite entire, with sclerotised, oblique baculi, setose apico-laterally; gonostyli cylindrical, attached before apices of gonocoxites, with three trichoid sensilla at apex. Proximal portion of vagina spirally twisted (Fig. 5E).

Sexual dimorphism. Females generally larger than males, with elytra somewhat wider in proportion to length (Table 6). Protibiae in males slightly expanded basally, sometimes with several extended setae; in females not expanded and without longer setae. Terminal maxillary palpomere in males wider than in females (Fig. 5A,B). 
Variability. The individual variability is, besides the dimensions (Table 6), most strongly pronounced in the colouration of the pubescence, which may be pale yellowish on most of the dorsal surfaces or darkened to various extent in posterior portions of pronotum and elytra or entirely brownish. The number of lateral ridges on metatibiae varies from three to five and those on metatarsomere 1 also from three to five.

DNA sequences. Two DNA sequences of 568-bp CO1-gene fragment are deposited in GenBank and BOLD databases with accession numbers listed in Table 3.

Distribution. Albania, Algeria, Austria, Croatia, Italy, France, Germany, Greece, Morocco, Spain, Switzerland, and Tunisia.

Natural history. The adults were collected on the xeric Mediterranean grasslands (Fig. 7A) and ruderal vegetation on the flowers of Apiaceae plants. The larva is not known.

\section{Mordellistena (s. str.) pseudorhenana Ermisch, 1977, status restituted}

(Figs. 1B, 2, 3, 4, 6, 7)

Mordellistena (s. str.) pseudorhenana Ermisch, 1977: 164 [original description as part of identification key, type locality: Érd, Hungary, first report from Hungary, Croatia, Bulgaria, and Macedonia]; Kaszab (1979: 41-42, Fig. 21C) [identification key, figures]; Batten (1980: 43) [synonymised with M. minima, description of M. nessebarica Batten, 1980 based on paratypes of M. pseudorhenana from Bulgaria].

Mordellistena (s. str.) minima: Ermisch (1963: 61-62) [first report from Cyprus]; Batten (1976: 167, 169, Fig. 5) [localities, first report from France and Spain, figure]; Batten (1977: 172-175, Figs. 20, 26) [figures, identification key, localities]; Odnosum (1992: 523, Pl. 251, Figs. 5-6) [identification key, figures, first report from Russian Far East]; Odnosum (1993: 24-26, Pl. 3, Fig. 26) [identification key, figure, first report from Ukraine]; Odnosum (2003: 36, 40, 46, Pl. 4, Fig. 5) [identification key, figures, first report from Kyrgyzstan]; Odnosum (2005: 95-108, Figs. 19, 45, 110) [identification key, figures, localities]; Horák (2008: 99) [catalogue, first report from Azerbaijan, Bulgaria, Greece, Israel, Turkey]; Odnosum (2010: 154, 195-197, Fig. 76) [identification key, description, figure, first report from Jordan]; Ruzzier (2013: 108) [localities]; Horák (2020: 96) [catalogue, first report from Slovakia].

Mordellistena sajoi Ermisch, 1977: 165 new synonymy [original description as part of identification key, type locality: Örszentmiklós, Nyáras [Örbottyán, Hungary]]; Kaszab (1979: 45) [identification key].

Type locality. Érd, Hungary.

Type material examined: Holotype of M. pseudorhenana, HNHM, male, labelled: “ $₫$ | Genitalpräparat | Érd Csiki | Coll. E. Csiki | Mordellistena nana Motsch. [handwritten] | Typus [red label] | pseudorhenana [handwritten] | Holotypus 1978 Mordellistena pseudorhenana Ermisch [handwritten, white label with red margins] | Mordellistena minima Costa det R. Batten 1977". A photograph of the holotype is available on Flickr (Selnekovič 2020). Paratype of M. pseudorhenana, HNHM, female, labelled: "Lesina [Hvar island] 1914 Horváth". Holotype of M. sajoi, HNHM, female, labelled: “Örszentmiklós Nyáras, Sajó | Holotypus 1978 Mordellistena sajoi Ermisch [handwritten; white label with red margins] | Staatl. Museum für Tierkunde. Dresden | MORDELLISTENA (s. str.) MINIMA Costa J. Horák det. 2017 | Mordellistena (s. str.) pseudorhenana Ermisch, 1977 D. Selnekovič det. 2020”. A photograph of the holotype is available on Flickr (Selnekovič 2020).

Additional material examined: Bosnia and Herzegovina: $1{ }^{\hat{\alpha}}$, Mostar env., in collection as

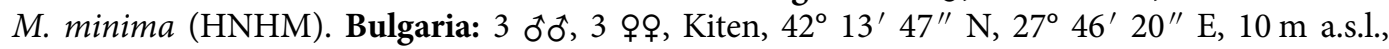
26.vii.2014, D. Selnekovič leg., ruderal vegetation, on flowers of Daucus carota (DSBS DS-37

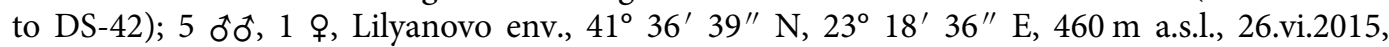
D. Selnekovič, dry grassland (DSBS DS-51 to DS-56); 2 ơ ô, 1 우, Lilyanovo env., $41^{\circ} 37^{\prime} 23^{\prime \prime} \mathrm{N}$, $23^{\circ} 19^{\prime} 41^{\prime \prime}$ E, $570 \mathrm{~m}$ a.s.l., 26.vi.2015, D. Selnekovič (DSBS DS-57 to DS-59); 6 ฮొరૈ, 2 우, 

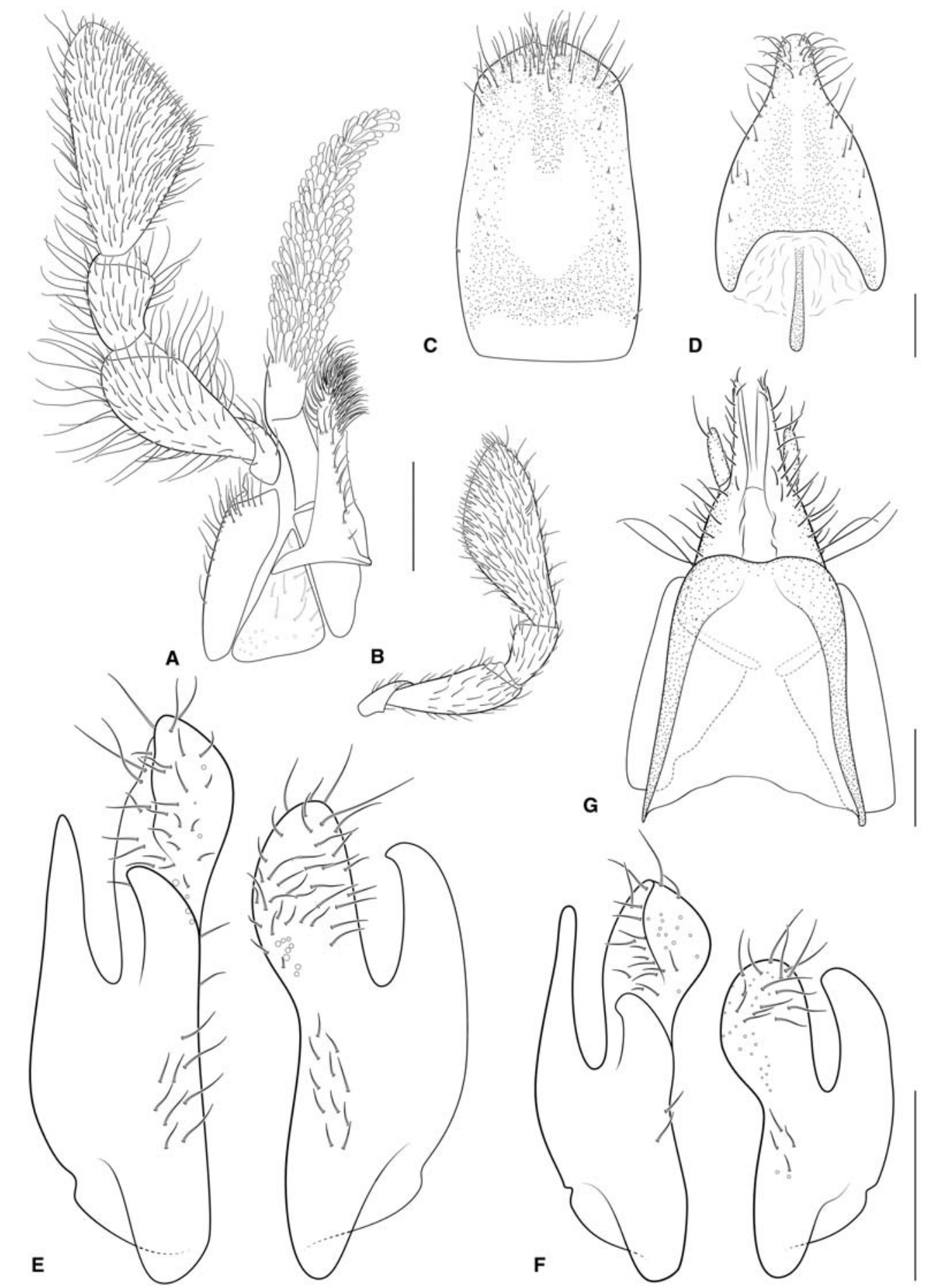

Fig. 6. Mordellistena pseudorhenana Ermisch, 1977. A, male maxilla; B, female maxillary palp; C, male abdominal sternite VIII; D, female abdominal sternite VIII; E, parameres (Cyprus, morphotype 2); F, parameres (holotype, morphotype 1); and G, ovipositor. 

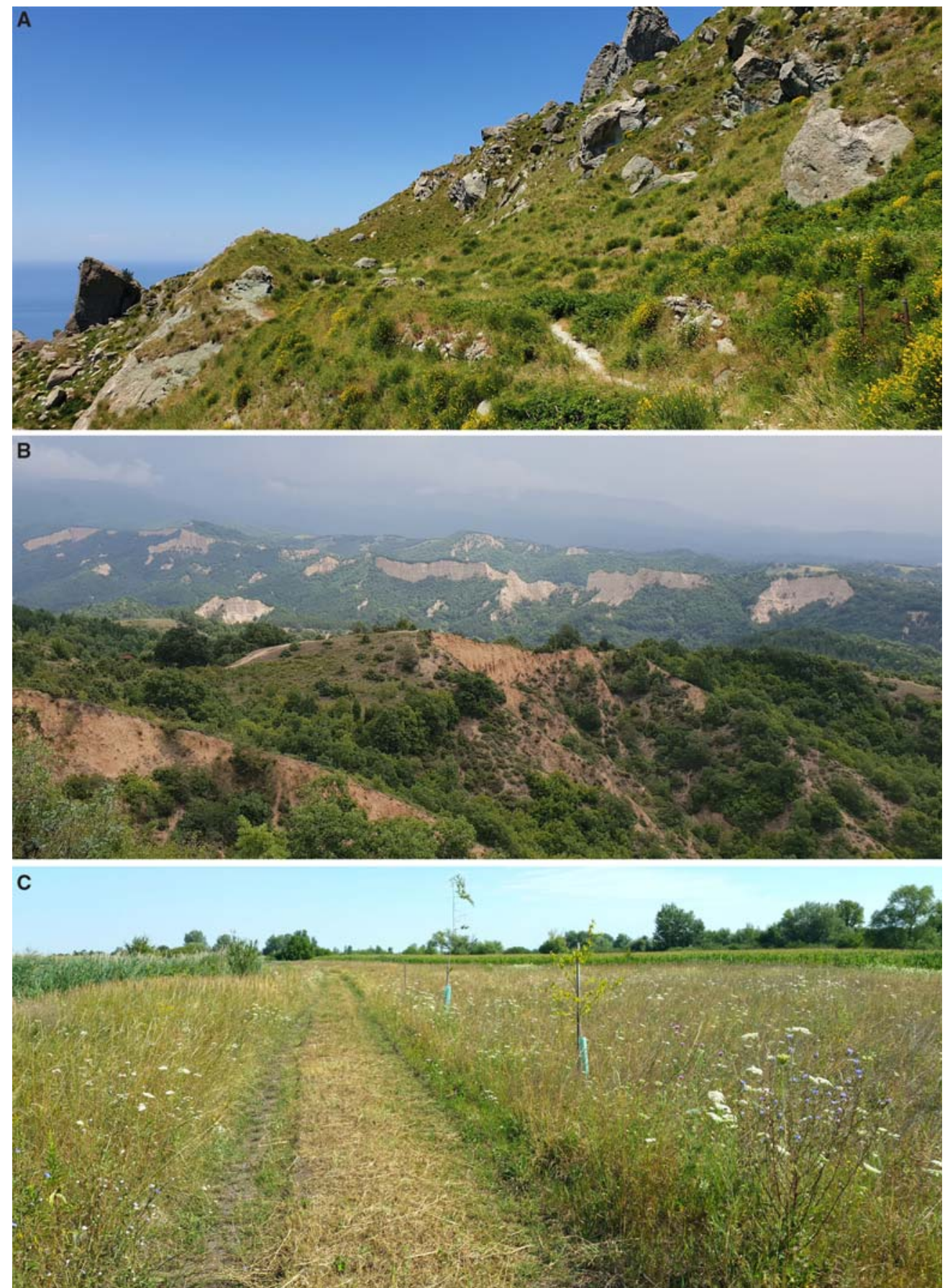

Fig. 7. Habitats of Mordellistena minima Costa, 1854 and M. pseudorhenana Ermisch, 1977. A, xeric grasslands near Serrara village, Ischia, Italy $\left(40^{\circ} 43^{\prime} 17^{\prime \prime} \mathrm{N}, 13^{\circ} 52^{\prime} 59^{\prime \prime} \mathrm{E}\right)$, with the presence of M. minima and M. pseudorhenana; B, xeric grasslands near Rozhen village, Pirin Mountains, Bulgaria $\left(41^{\circ} 31^{\prime} 51^{\prime \prime} \mathrm{N}, 23^{\circ} 25^{\prime} 23^{\prime \prime} \mathrm{E}\right)$, with the presence of M. pseudorhenana; and C, ruderal habitat near Chotín village, Slovakia ( $\left.47^{\circ} 48^{\prime} 28^{\prime \prime} \mathrm{N}, 18^{\circ} 11^{\prime} 53^{\prime \prime} \mathrm{E}\right)$, with the presence of M. pseudorhenana. 
Melnik env., $41^{\circ} 30^{\prime} 43^{\prime \prime} \mathrm{N}, 23^{\circ} 22^{\prime} 46^{\prime \prime}$ E, $335 \mathrm{~m}$ a.s.l., 27.vi.2015, D. Selnekovič, dry grassland, on flowers of Daucus carota (DSBS DS-43 to DS-50); 5 o $^{\circ} 0^{\star}, 1$, , Rozhen env., $41^{\circ} 31^{\prime} 51^{\prime \prime} \mathrm{N}, 23^{\circ} 25^{\prime} 23^{\prime \prime} \mathrm{E}$, $630 \mathrm{~m}$ a.s.l., 25.vii.2018, D. Selnekovič \& Z. Peczová leg., xeric sandy steppe (DSBS DSBS_6 to DSBS_8 and DS-148 to DS-150). Croatia: 1 ot, "Curzola" [Korčula island], 1914, Horváth leg., in collection as M. minima (HNHM); 2 ơ , Dubrovnik, Lokrum island, 2.viii.1958, Endrödy-

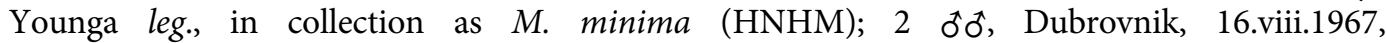
S. Horvatovich leg., "Meeresküste" [seashore], in collection as M. minima (HNHM); 1 đo, 3 우, Jablanac, 27-28.vii.1969, S. Horvatovich leg., in collection as M. minima (HNHM). Cyprus: 1 o, 1 ㅇ, Larnaka, Glaszner leg., R. Batten identified as M. grisea Mulsant, 1856 in 1979 (HNHM); 24 꾹, 7 우우; Limassol, Germasogeia reservoir, $34^{\circ} 45^{\prime} 19^{\prime \prime} \mathrm{N}, 33^{\circ} 05^{\prime} 36^{\prime \prime} \mathrm{E}, 80 \mathrm{~m}$ a.s.l., 27.iv.2018, D. Selnekovič leg., dry grassland, on flowers of Apiaceae (DSBS DS-73 to DS-84, DS-112 to DS-113, DS-170 to DS-180, DSBS_9, DSBS_10, DSBS_12 to DSBS_14). Israel: 1 ô, Jerusalem, Reitter leg., in collection as M. minima (HNHM DS-187). Italy: 4 ô ô, 1 , Ischia Island, Serrara env., $40^{\circ} 42^{\prime} 60^{\prime \prime} \mathrm{N}, 13^{\circ} 53^{\prime} 11^{\prime \prime}$ E, $517 \mathrm{~m}$ a.s.l., 29.vi.2019, D. Selnekovič leg., ruderal vegetation, on flowers of Daucus (DSBS DS-169, DSBS_51 to DSBS_54); 6 đð, 2 우, Ischia Island, Serrara env., $40^{\circ} 43^{\prime} 17^{\prime \prime} \mathrm{N}, 13^{\circ} 52^{\prime} 59^{\prime \prime}$ E, $550 \mathrm{~m}$ a.s.l., 30.vi.2019, D. Selnekovič leg., dry grassland, on flowers of Daucus (DSBS DS-116 to DS-118, DS-181 to DS-185). Montenegro: 1 o, 1 , Sutorman, Apfelbeck leg., in collection as M. minima (HNHM); 1 o, Zelenika, viii.1906, Horváth leg. (HNHM); 1 đo, 1 ㅇ, Budva, 9.vii.1958, Kaszab \& Székessy

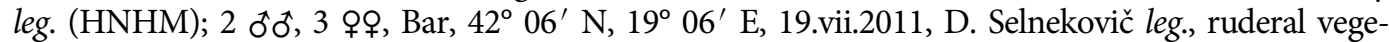
tation, on flowers of Daucus carota (DSBS DS-12 to DS-16); 2 o $^{\prime}, 2$ 우, Bar, Stari Bar, $42^{\circ} 05^{\prime} 31^{\prime \prime} \mathrm{N}$,

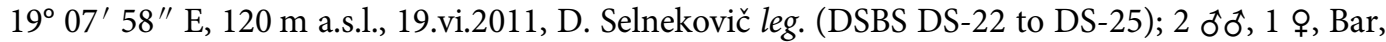
Volujica hill, $42^{\circ} 04^{\prime} 16^{\prime \prime} \mathrm{N}, 19^{\circ} 06^{\prime} 10^{\prime \prime} \mathrm{E}, 110 \mathrm{~m}$ a.s.l., 20.vi.2011, D. Selnekovič leg., dry grassland

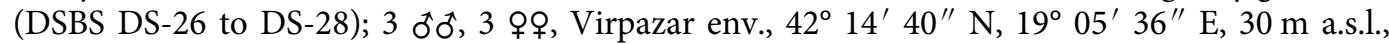
21.vi.2011, D. Selnekovič leg. (DSBS DS-29 to DS-34); 3 ડొరో, 2 우, Bar, Ribnyak monastery env., $42.13222^{\circ} \mathrm{N}, 19.12583^{\circ} \mathrm{E}, 215 \mathrm{~m}$ a.s.l., 22.vi.2011, D. Selnekovič leg., dry grassland, on flowers of Helichrysum (DSBS DS-17 to DS-21). Slovakia: 6 ơ $^{\top}, 3$ 우, Bratislava, Lamač, $48^{\circ} 11^{\prime} 20^{\prime \prime} \mathrm{N}$, $17^{\circ} 03^{\prime} 30^{\prime \prime}$ E, ca. $280 \mathrm{~m}$ a.s.l., 15.vii.2008, O. Šauša leg. (DSBS DS-02 to DS-10); 1 ơ, Rajecké

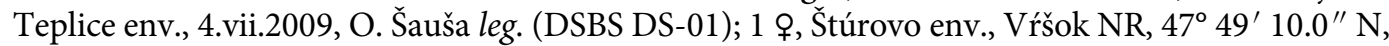
$18^{\circ} 39^{\prime} 28.4^{\prime \prime}$ E, $190 \mathrm{~m}$ a.s.l., 10.vi.2011, D. Selnekovič leg., Pannonian steppe (DSBS DS-11); 1 \&, Bratislava, Ostrov Kopáč NR, $48^{\circ} 06^{\prime} 04^{\prime \prime} \mathrm{N}, 17^{\circ} 09^{\prime} 34^{\prime \prime}$ E, $130 \mathrm{~m}$ a.s.l., 7.viii.2011, D. Selnekovič leg., Pannonian steppe (DSBS DS-35); 1 ㅇ, Hajnačka env., Tilič hill, $48^{\circ} 12^{\prime} 28^{\prime \prime} \mathrm{N}$, $19^{\circ} 55^{\prime} 53^{\prime \prime}$ E, $450 \mathrm{~m}$ a.s.l., 13.vii.2013, D. Selnekovič leg., dry steppe (DSBS DS-36); 1 ㅇ, Tvrdošovce env., $48^{\circ} 05^{\prime} 30^{\prime \prime} \mathrm{N}, 18^{\circ} 02^{\prime} 03^{\prime \prime} \mathrm{E}, 110 \mathrm{~m}$ a.s.l., 23.vii.2015, D. Selnekovič leg., ruderal vegetation along field margin (DSBS DS-60); $60^{\top} 0^{\top}, 5$ 우, Tvrdošovce env., $48^{\circ} 06^{\prime} 01^{\prime \prime} \mathrm{N}$, $18^{\circ} 01^{\prime} 59^{\prime \prime}$ E, $110 \mathrm{~m}$ a.s.l., 26.vii.2016, D. Selnekovič leg., salt marsh (DSBS DS-61 to DS-71);

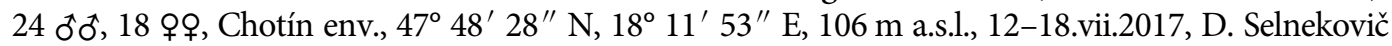
leg., ruderal vegetation (DSBS DS-85 to DS-111, DS-123 to DS-137); 3 ઠðð, 1 ㅇ, Chotín env., $47^{\circ} 48^{\prime} 28^{\prime \prime} \mathrm{N}, 18^{\circ} 11^{\prime} 53^{\prime \prime}$ E, $106 \mathrm{~m}$ a.s.l., 20.vi.2019, D. Selnekovič leg., ruderal vegetation (DSBS DSBS_43 to DSBS_46); 1 ㅇ, Virt env., $47^{\circ} 45^{\prime} 35^{\prime \prime} \mathrm{N}, 18^{\circ} 20^{\prime} 21^{\prime \prime}$ E, $115 \mathrm{~m}$ a.s.l., 10.viii.2017, D. Selnekovič leg., ruderal vegetation along field margin, on flowers of Daucus carota (DSBS DS-72); $20^{\circ} 0^{\star}$, Virt env., $47^{\circ} 45^{\prime} 36^{\prime \prime} \mathrm{N}, 18^{\circ} 20^{\prime} 26^{\prime \prime} \mathrm{E}, 110 \mathrm{~m}$ a.s.l., 9.vii.2019, D. Selnekovič leg., ruderal vegetation along field margin, on flowers of Daucus carota (DSBS DSBS_59, DSBS_62);

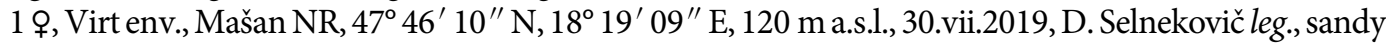
steppe, on flowers of Seseli (DSBS DS-122); 1 ơ, Iža env., Bokroš salt marsh NR, $47^{\circ} 44^{\prime} 53^{\prime \prime} \mathrm{N}$, $18^{\circ} 15^{\prime} 38^{\prime \prime}$ E, 107 m a.s.l., 29.vii.2019, D. Selnekovič leg., grazed salt marsh, on flowers of Daucus carota (DSBS DS-120). Slovenia: 3 ఫో, Drežnica, Apfelbeck leg., in collection as M. minima (HNHM). Switzerland: 1 ㅇ, "Helvetia", in collection as M. perroudi (SDEI Col-11369). Turkey: 1 đ, 1 우, Istanbul, 20.vi.1925, Biró leg., in collection as M. minima (HNHM DS-186). Ukraine: 2 우, Krim, Alusta, 18.vi.1956, L. Horváth leg., in collection as M. minima (HNHM). 
Differential diagnosis. Mordellistena pseudorhenana can be characterised by the following combination of characters: (1) body including mouthparts, antennae, and legs black (Fig. 1B); (2) pubescence on dorsal surfaces yellowish or pale brownish with purple sheen; (3) galea long, apically pointed (Fig. 6A); (4) antennomeres 5-10 ca. 1.20-1.30 times longer than wide; (5) protibiae in males expanded basally, with distinct clusters of extended setae; (6) metatibiae with three lateral ridges, the second one being the longest and the third one usually the shortest; (7) abdominal sternite VIII in males 1.50-1.60 times longer than wide, with $c a$. parallel lateral margins (Fig. 6C); in females, apically produced and rounded, with spiculum ventrale narrowly clavate (Fig. 6C); and (8) parameres and ovipositor as in Figure 6E,F,G.

Based on the morphology, the species can be assigned to the $M$. confinis species group as defined by Ermisch (1956). From other members of the group, it can be differentiated based on the long and pointed galea (Fig. 6A), in combination with short antennomeres 5-10, expanded protibiae with distinct clusters of extended setae in males, and completely black-coloured body. Such form of galea is also present in M. grisea Mulsant, 1856 (sensu Batten 1977), but it can be differentiated from $M$. pseudorhenana by its protibiae not being expanded in males and by parameres of different shape.

Redescription. Body slender, wedge-shaped, widest at proximal one-half of elytra, dorsum moderately convex, venter strongly so (Fig. 1B). Metric characters are provided in Tables 1 and 6. Colour of almost all surfaces uniformly black with fine bluish sheen; anterior margin of frontoclypeus, mandibles, lacinia, galea, and labium, including palpi, brownish. Vestiture consisting of dense, decumbent, dorso-ventrally flattened setae; colour uniformly light-yellowish on head and sternal thoracic parts; in anterior one-half of pronotum light-yellowish and slightly darkened postero-medially; in antero-lateral portions of elytra light-yellowish and gradually darkened postero-medially to completely black in apical portions; on femora and proximal portions of tibiae light-yellowish and gradually darkened distally; on abdominal ventrites 1-2 light-yellowish, gradually darkened on following ventrites to entirely black on ventrite 5 and pygidium; vestiture on elytra with strong purple sheen.

Head moderately convex dorsally; anterior margin of frontoclypeus straight; occipital carina evenly rounded in dorsal view, straight to slightly concave in posterior view; tempora absent; dorsal surface very finely microreticulated, with minute, round setiferous punctures. Labrum transverse, microreticulate, with setiferous punctures, exposed portion ca. 2.50 times wider than long, anterior margin and antero-lateral angles rounded. Eyes broadly oval, $c a .1 .40$ times longer than wide, not extending onto ventral surfaces, finely faceted with distinctly apparent interfacetal setae. Antennae moderately long, feebly serrate (Fig. 1B); scapus and pedicel cylindrical, subequal; antennomeres 3-4 slightly shorter than previous and distinctly shorter than following, subequal; antennomeres 5-10 subequal, in males ca. 1.20-1.30 times and in females ca. 1.10 times longer than wide; antennomere 11 oval, ca. 1.80 times longer than wide. Mandibles symmetrical except in molar parts, bidentate, with lateral exposed portion setose; mola denticulate; prostheca with thin, medially oriented setae. Maxilla as in Figure 6A,B; galea almost as long as maxillary palp, pointed at apex, densely covered with trichoid and distally expanded, spoon-like sensilla; lacinia with trichoid sensilla arranged in longitudinal row and scattered in apical portions; palpifer subcylindrical, setose antero-laterally; maxillary palpomere 1 short, setose ventrally; maxillary palpomere 2 cylindrical, widened apically, in males wider than in females; maxillary palpomere 3 short, widened apically; maxillary palpomere 4 securiform, $c a$. 2.40 times longer than wide, with inner angle situated behind middle; maxillary palpomeres $2-3$ in males with very long setae on ventral surfaces. Terminal labial palpomere broadly fusiform.

Pronotum convex, slightly transverse (Table 6), widest around middle; anterior margin slightly produced in middle, anterior margination complete, anterior angles rounded; lateral carinae rounded in dorsal aspect, slightly concave in lateral aspect, lateral margination inapparent but complete; posterior angles slightly obtuse, narrowly rounded; surface finely microreticulate, with rasp-like setiferous punctures. Hypomeron with large concavity for reception of procoxae. Prosternal 
process obliterated. Scutellar shield triangular, punctuate, and setose. Mesoventral process as wide at apex as mesotibia, truncate. Metaventral discrimen inapparent. Metanepisternite with exposed portion rather wide, distally narrowed; lateral margin concave, mesal margin straight.

Elytra moderately convex, evenly and strongly narrowed posteriorly, widest at end of first one-quarter, EL/EW ratio in Table 6; lateral carinae rounded, strongly convergent behind first one-quarter (Fig. 1B); apices separately rounded; surface with fine microreticulation formed by transverse, undulate lines and with rasp-like setiferous punctures.

Protibiae straight, distinctly dilated basally and with fringe of long, medially oriented setae in males; mesotibiae slightly bent medially; metatibiae with one apical and three lateral ridges parallel to apical tibial margin; second lateral ridge is usually distinctly longer than first one, not reaching beyond one-half of tibial width; third lateral ridge often short and inapparent; metatibial spurs black, outer one ca. 0.70 times as long as inner one. Protarsi about as long as protibiae, protarsomere 1 as long as following two tarsomeres combined; protarsomere 4 distinctly longer than wide with anterior margin slightly concave; protarsal claws tridentate; mesotarsi $c a$. 1.30 times as long as mesotibiae; metatarsomere 1 with three ridges, metatarsomere 2 with two ridges, metatarsomere 3 without ridges.

Pygidium moderately long (Table 6), slightly bent ventrally in lateral aspect, about twice as long as ventrite 5. Ventrite 5 with apical margin rounded. Sternite VIII in males $c a$. 1.50-1.60 times longer than wide, setose apically, with lateral margins slightly convergent, postero-lateral angles distinct, rounded, apical margin slightly sinuated in middle (Fig. 6C); in females, ca. 1.50-1.60 times longer than wide, setose apico-laterally, strongly produced and narrowly rounded apically, with basal margin broadly concave, spiculum ventrale narrowly clavate (Fig. 6D). Sternite IX in males slender, arrow-shaped. Phallobase long, ca. 0.60 times as long as elytra, with distal arms ca. 4.00 times as long as tubular part. Median lobe very long and narrow, ca. 1.20 times as long as elytra, slightly expanded, and pointed apically. Dimensions of parameres as in Table 1. Right paramere (Fig. 6E,F) with basal part subequal to distinctly longer than the branches, setose dorso-medially; ventral branch shorter than dorsal one, slightly bent dorsally; dorsal branch wide, setose, rounded apically. Left paramere (Fig. 6E,G) with basal part about as long as dorsal branch, setose dorso-medially; ventral branch rather long, narrowly rounded apically; dorsal branch setose, moderately expanded, and obliquely truncate apically; medial process large, bent ventrally. Ovipositor (Fig. 6G) slightly sclerotised except for baculi; paraprocts slightly shorter than gonocoxites, with narrow, heavily sclerotised baculi; proctiger rather long with heavily sclerotised baculi, with apical margin sinuate; gonocoxites rather long and narrow, not divided, setose, with heavily sclerotised, oblique baculi; gonostyli cylindrical, attached well before apices of gonocoxites, bearing three trichoid sensilla at apices.

Sexual dimorphism. Antennomeres 5-10 in males slightly longer, ca. 1.20-1.30 times longer than wide, whereas in females they are ca. 1.10 times longer than wide. Maxillary palpomeres 1-3 in males bearing very long setae on the ventral surface; palpomeres 2 and 4 in males wider than in females (Fig. 6 A,B). Protibiae in males basally expanded, with group of longer, medially oriented setae; in females, simple, without extended setae.

Variability. The colour of pubescence on the dorsal surfaces varies from pale yellowish to darkened to various extents in posterior portions of pronotum and elytra to completely brownish. Rather distinct differences can be found in the shape and dimensions of the parameres between the morphotype 1 represented by holotype plus all the examined male specimens from Europe and the morphotype 2 represented by male specimens from Cyprus, Israel, and Turkey (Figs. 2, 3, 6 E,F; Table 1; Supplementary material, Table S1). The specimens of morphotype 2 have their parameres longer (Table 1), with the basal part of the right paramere longer and the dorsal process of the left paramere longer and narrower than in the morphotype 1 (Fig. 6 E,F). The barcoding region of $\mathrm{CO} 1$ gene shows very small differences between the representatives of the two morphotypes $(0.18-1.43 \%$; Table 5). 
DNA sequences. Eighteen DNA sequences of the 568-bp CO1 gene fragment are deposited in GenBank and BOLD databases, with accession numbers listed in Table 3.

Distribution. Azerbaijan, Bosnia and Herzegovina (first record), Bulgaria, Croatia, Cyprus, France, Greece, Hungary, Italy, Israel, Jordan, Kyrgyzstan, Macedonia, Montenegro (first record), Slovakia, Slovenia (first record), Spain, Switzerland (first record), Turkey, and Ukraine. Horák $(2008,2020)$ reports this species from the former Yugoslavia (present Serbia and Montenegro) without specifying the country. The report from Russian Far East by Odnosum (1992) is probably based on misidentification. Mordellistena pseudorhenana is reported here for the first time from Bosnia and Herzegovina, Montenegro, Slovenia, and Switzerland.

Natural history. The adults were found on the flowers of herbaceous plants, for example, Daucus carota Linnaeus, Seseli sp. (Apiaceae), Galium sp. (Rubiaceae), and Helichrysum sp. Miller (Asteraceae), in various grassland and ruderal habitats (Fig. 7) from June to August in altitudes $10-630 \mathrm{~m}$ above sea level. The larva of $M$. pseudorhenana is not known. The first author's efforts to obtain and rear larvae from the stems of Cirsium arvense (Linnaeus), Centaurea sp. (Asteraceae), and Daucus carota Linnaeus (Apiaceae) collected from two localities - Chotín (Fig. 7C) and Tvrdošovce, Slovakia - with abundant populations of the species were unsuccessful.

Remarks. Mordellistena sajoi Ermisch, 1977 was briefly described in the identification key based on a single female specimen. The re-examination of the holotype revealed it is conspecific with $M$. pseudorhenana, and we consider it a new junior subjective synonym of the latter.

\section{Discussion}

Revision of the type material is of great importance for future research in the European Mordellidae. Results of our recent studies show that re-examination of type material can reveal surprising findings regarding the identity and status of the taxa, including the common and widespread species (Horák 1990, 1996; Selnekovič and Kodada 2019; Selnekovič and Improta 2020). Naturally, searching for and obtaining the type material from museum collections can complicate the taxonomic work, especially when specimens cannot be found - for example, much of E. Mulsant's material. However, once the type specimens are documented and the species are redescribed and properly delimited based on morphological and molecular markers, modern identification methods such as DNA barcoding allow easier recognition of the species and can provide the basis for further studies in different fields, such as ecology, phylogeography, or development.

We used DNA barcodes for the first time to examine the genetic divergences between European Mordellidae species and to interpret the morphological variability observed in M. pseudorhenana. We were able to provide the DNA barcodes of $\mathrm{CO} 1$ gene fragments conventionally used for species identification from five species of the Mordellistena confinis species group with revised and documented type material (Horák 1996; Selnekovič and Kodada 2019). The species showed wide genetic divergence even between morphologically similar species - for example, M. minima and M. lindbergi (19.3\%), and M. hirtipes and M. purpurascens (13.8\%; Table 4) - corresponding to results in other beetle groups (e.g., Raupach et al. 2010; Pentinsaari et al. 2014). In contrast to high divergence between species, the mean intraspecific divergences were considerably less, up to $1.9 \%$ in $M$. hirtipes. The incongruence between morphological and molecular evidence appeared in M. pseudorhenana. Based on the differences in the shape and dimensions of parameres, we were able to identify two distinct morphotypes (Figs. 2, 3A, 6E,F; Table 1). To help us with the interpretation of such differences in morphology, we compared the intra- and interspecific Kimura 2-parameter divergences. Although no universal threshold exists for separating species based on the genetic divergences, the comparison of intra- and interspecific distances with the presence of a distinct genetic gap proved to be useful for species separation in beetles (e.g., Raupach et al. 2010; Woodcock et al. 2013; Pentinsaari et al. 2014). The highest intraspecific Kimura 2-parameter distance within M. pseudorhenana (1.4\%) was 11.8 times less than the smallest interspecific distance 
between $M$. pseudorhenana and M. lindbergi (16.8\%). Furthermore, the intraspecific Kimura 2-parameter distances within M. pseudorhenana ranged from 0.2 to $1.4 \%$, with no distinct gap. Such low genetic divergence between the two morphotypes does not provide evidence for establishing the morphotypes as separate species.

The discrepancy between the morphological and molecular evidence opens the discussion about the efficiency of using the conventional DNA barcoding marker (CO1) for testing the taxonomic boundaries and verifying the status of the species within the family Mordellidae. It also raises questions about the validity of species that have been defined by rather weak morphological differences. The broader datasets, a combination of multiple genes, and the use of more advanced tools in molecular taxonomy such as character-based DNA barcoding should yield more insights into the taxonomy of this problematic group.

Acknowledgements. The authors thank Ottó Merkl (Hungarian Natural History Museum), Brend Jäger (Museum für Naturkunde, Humboldt-Universität zu Berlin), and Mandy Schröter (Senckenberg Deutsches Entomologisches Institut) for providing access to museal collections and landing the material. The authors thank Jan Horák, Michal Šagát, and two anonymous reviewers for their valuable comments and suggestions. The present study was supported by the Slovak Research and Development Agency under the contract No. APVV-19-0076 and by the European Commission programme LIFE12 NAT/SK/001137: BeeSandFish, action D1.

Supplementary material. To view supplementary material for this article, please visit https://doi.org/10.4039/tce.2021.3.

\section{References}

Angelini, F. 1986. Coleotterofauna del Massiccio del Pollino (Basilicata-Calabria) (Coleoptera). Entomologica, 11: 37-125.

Batten, R. 1976. Mordellidae (Coleoptera) from the South of France and Pyrenees. Entomologische Berichten, 36: 164-171.

Batten, R. 1977. Two new Mordellidae (Coleoptera) from Southern Europe, and a key to the Mordellistena micans group. Entomologische Berichten, 37: 167-176.

Batten, R. 1980. Notes on the Mordellistena gemellata group: two new species and a case of synonymy (Coleoptera, Mordellidae). Entomologische Berichten, 40: 41-46.

Compte, A. 1985. Mordellidae de las islas Baleares (Coleópteros). Actas do II Congresso Ibérico de Entomologia, 1985: 57-66.

Costa, A. 1854. Parte 1 a. Coleotteri, Eteromeri. Famiglia de'Mordellidei - Mordellidea. In Fauna del regno di Napoli ossia enumerazione de tutti gli animali che abitano le diverse regioni di questo regno e la acque che la bagnano contenente la descrizione de'nuovi o poco esattamente conosciuti noc figure ricavete da originali vivente e dipinte al naturale. Edited by O.G. Costa. Gaetano Sautto, Naples, Italy.

Darriba, D., Taboada, G.L., Doallo, R., and Posada, D. 2012. jModelTest 2: more models, new heuristics and parallel computing. Nature Methods, 9: 772. https://doi.org/10.1038/nmeth.2109.

Emery, M.C. 1876. Essai monographique sur les Mordellides de l'Europe et des contrées limitrophes. L'Abeille: Journal d'Entomologie, 14: 1-128.

Ermisch, K. 1954. Mordellistena. Studien I. Mordellistena micans Germar und die micans der Autoren. Beiträge zur Entomologie, 4: 173-180.

Ermisch, K. 1956. Mordellidae. In Faunistik der mitteleuropäischen Käfer. Band 5: Heteromera. Edited by A. Horion. Entomologische Arbeiten aus dem Museum G. Frey Tutzing bei München, München, Germany. Pp. 269-328.

Ermisch, K. 1963. Die Mordelliden der Insel Cypren (Coleoptera, Heteromera, Mordellidae). Notuale Entomologicae, 43: 49-67. 
Ermisch, K. 1969a. Ergebnisse der Albanien-Expedition 1961 des Deutschen Entomologischen Institutes, 76. Beitrag, Coleoptera: Mordellidae. Beiträge zur Entomologie, 19: 845-859.

Ermisch, K. 1969b. 79. Familie: Mordellidae. In Die Käfer Mitteleuropas. Band 8, Teredilia, Heteromera, Lamellicornia. Edited by H. Freude, K.W. Harde, and G.A. Lohse. Goecke \& Evers, Krefeld; G. Fischer, Jena, Stuttgart, Germany. Pp. 160-196.

Ermisch, K. 1977. Die Mordellistena-Arten Ungarns und benachbarter Gebeite sowie Beschreibung einer neuen Hoshihananomia-Art aus Siebenbürgen (Coleoptera, Mordellidae). Folia Entomologica Hungarica (Series Nova), 30: 151-177.

Folmer, O., Black, M., Hoeh, W., Lutz, R., and Vrijenhoek, R. 1994. DNA primers for amplification of mitochondrial cytochrome c oxidase subunit I from diverse metazoan invertebrates. Molecular Marine Biology and Biotechnology, 3: 294-299.

Franciscolo, M.E. 1942. Mordellidi raccolti dal Marchese G. Doria all'isola del Giglio negli anni 1900-1902. Materiali per una fauna dell'arcipelago Toscano XXI. Bollettino della Società Entomologica Italiana, 74: 6-10.

Franciscolo, M.E. 1956. Ricerche zoologiche sul Massiccio del Pollino. XVIII. Coleoptera. 8. Mordellidae, Scraptiidae. Annuario dell'Istituto e Museo di Zoologia della Università di Napoli, 8: 1-7.

Franciscolo, M.E. 1957. Coleoptera: Mordellidae. A monograph of the South African genera and species; 1. morphology, subfamily Ctenidiinae and tribe Stenaliini. In South African animal life: results of the Lund University Expedition in 1950-1951. Vol. 4. Edited by B. Hanström, P. Brinck, and G. Rudebeck. Almqvist and Wiksell, Stockholm, Sweden. Pp. 207-291.

Franciscolo, M.E. 1991. Su alcuni Mordellidi e Scraptiidi (Coleopetra - Heteromera) delle Isole Pelagie. Naturalista Siciliano, 15: 167-178.

Gemminger, M. and Harold, B. von 1870. Familia LVIII. Mordellidae. In Catalogus coleopterorum hucusque descriptorum synonymicus et systematicus. Tom VII. Tenebrionidae, Nilionidae, Pythidae, Melandryidae, Lagriidae, Pedilidae, Anthicidae, Pyrochroidae, Mordellidae, Rhipidophoridae, Cantharidae, Oedemeridae. E.H. Gummi, München, Germany. Pp. 2105-2117.

Hammer, Ø., Harper, D.A.T., and Ryan, P.D. 2001. PAST: paleontological statistics software package for education and data analysis. Palaeontologia Electronica, 4: 1-9. Available from http://palaeo-electronicaorg/2001_1/past/issue1_01.htm.

Heyden, L. von, Reitter, E., and Weise, J. 1883. Catalogus coleopterorum Europae et Caucasi. Editio tertia. Libraria Nicolai, Berlin, Germany.

Heyden, L. von, Reitter, E., and Weise, J. 1906. Catalogus coleopterorum Europae, Caucasi et Armeniae Rossicae. Editio secunda. Friedländer \& Sohn, Berlin, Germany.

Horák, J. 1990. Typenrevision einiger wenig bekanntner Arten aus der Gattung Mordellistena Costa (Insecta, Coleoptera: Mordellidae). Entomologische Abhandlungen, 53: 125-142.

Horák, J. 1996. Revision of some little known species of genus Mordellistena with description of two new species. Part 2. Klapalekiana, 32: 171-184.

Horák, J. 2008. Family Mordellidae Latreille, 1802. In Catalogue of Palaearctic Coleoptera. Vol. 5. Tenebrionoidea. Edited by I. Löbl and A. Smetana. Apollo Books, Stenstrup, Denmark.

Horák, J. 2020. Family Mordellidae Latreille, 1802. In Catalogue of Palaearctic Coleoptera. Vol. 5. Tenebrionoidea. Revised and Updated Second Edition. Edited by D. Iwan and I. Löbl. Brill, Leiden, Boston.

International Trust of Zoological Nomenclature. 1999. International Code of Zoological Nomenclature. Fourth edition. International Trust for Zoological Nomenclature, London, United Kingdom. https://doi.org/10.5962/bhl.title.50608.

Kaszab, Z. 1979. Felemás lábfejízes bogarak II. Heteromera II. (Mordellidae), Fauna Hungariae. 134. Akadémiai Kiadó, Budapest, Hungary.

Kearse, M., Moir, R., Wilson, A., Stones-Havas, S., Cheung, M., Sturrock, S., et al. 2012. Geneious Basic: an integrated and extendable desktop software platform for the organization and analysis 
of sequence data. Bioinformatics, 28: 1647-1649. https://oi.org/10.1093/bioinformatics/ bts199.

Kimura, M. 1980. A simple method for estimating evolutionary rates of base substitutions through comparative studies of nucleotide sequences. Journal of Molecular Evolution, 16: 111-120. https://doi.org/10.1007/BF01731581.

Köstlin, R. and Vogt, H. 1971. Beitrag zur Mordellidenfauna. Mitteilungen des Entomologischen Vereins Stuttgart, 6: 35-74.

Kumar, S., Stecher, G., Li, M., Knyaz, C.H., and Tamura, K. 2018. MEGA X: molecular evolutionary genetics analysis across computing platforms. Molecular Biology and Evolution, 35: 1547-1549. https://doi.org/10.1093/molbev/msy096.

Lawrence, J.F. and Ślipiński, A. 2010. 11.7 Mordellidae Latreille, 1802. In Coleoptera, Beetles. Volume 2: Morphology and systematics (Elateroidea, Bostrichiformia, Cucujiformia partim). Edited by R.A.B. Leschen, R.G. Beutel, and J.F. Lawrence. In Handbook of Zoology. A natural history of the phyla of the animal kingdom. Volume IV: Arthropoda: Insecta. Edited by N.P. Kristensen and R.G. Beutel. Walter de Gruyter, Berlin, Germany and New York, United States of America. Pp. 533-537. https://doi.org/10.1515/9783110911213.533.

Lu, W., Jackman, J.A., and Johnson, P.W. 1997. Male genitalia and phylogenetic relationships in North American Mordellidae (Coleoptera). Annals of the Entomological Society of America, 90: 742-767. https://doi.org/10.1093/aesa/90.6.742.

Mulsant, E. 1856. Histoire des coléoptères de France. Barbipalpes, longipedes, latipennes. Annales de la Société Linnéenne de Lyon (N.S.), 3: 193-544.

Odnosum, V.K. 1992. Sem. Mordellidae - gorbatki ili shiponoski. In Opredelitel nasekomych Dalnego Vostoka SSSR v shestykh tomakh. Tom III. Zhestokrylye, ili zhuki. Chast 2. Edited by P.A. Ler. Nauka, Saint Petersburg, Russia. Pp. 517-526. [in Russian]

Odnosum, V.K. 1993. Subfamily Mordellinae mordellid beetles (Coleoptera, Mordellidae) of the Ukrainian fauna. Communication 2. Vestnik Zoologii, 1993: 20-28. [in Russian]

Odnosum, V.K. 2003. Mordellid beetles (Coleoptera, Mordellidae) in the fauna of Kazakhstan and Middle Asia. Communication 2. Vestnik Zoologii, 37: 33-49. [in Russian]

Odnosum, V.K. 2005. Zhuki-gorbatki (Coleoptera: Mordellidae) fauni tsentralnoi i vostochnoi Evropi. Soobshchenie 2. Podsemeistvo Mordellinae. Triba Mordellistenini. The Kharkov Entomological Society Gazette, 11: 93-112. [in Russian]

Odnosum, V.K. 2009. Review of mordellid beetles of the Mordellistena confinis group (Coleoptera, Mordellidae). Vestnik Zoologii, 43: 3-14. [in Russian]

Odnosum, V.K. 2010. Zhuki gorbatki (Coleoptera, Mordellidae). Fauna Ukrainy. Volume 19. Part 9. Naukova Dumka, Kiev, Ukraine. [in Ukrainian]

Pentinsaari, M., Hebert, P.D.N., and Mutanen, M. 2014. Barcoding beetles: a regional survey of 1872 species reveals high identification success and unusually deep interspecific divergences. PLOS One, 9: e108651. https://doi.org/10.1371/journal.pone.0108651.

Raupach, M.J., Astrin, J.J., Hannig, K., Peters, M., Stoeckle, M.Y., and Wägele, J.W. 2010. Molecular species identification of Central European ground beetles (Coleoptera: Carabidae) using nuclear rDNA expansion segments and DNA barcodes. Frontiers in Zoology, 7: 26. http://doi.org/10.1186/1742-9994-7-26.

Roubal, J. 1934. Inventa entomologica itineris Hispanici et Maroccani, quod a. 1926 fecerunt Harald et Håkan Lindberg. XIX. Scydmaenidae, Pselaphidae, Mordellidae. Commentationes Biologicae, 4: 4-7.

Ruzzier, E. 2013. Taxonomic and faunistic notes on Italian Mordellidae (Coleoptera Tenebrionoidea) with redescription of Falsopseudotomoxia argyropleura (Franciscolo, 1942) n. comb. Bollettino della Società Entomologica Italiana, 145: 103-115. http://dx.doi.org/10. 4081/BollettinoSEI.2013.103.

Schaufuss, C. 1916. Calwer's Käferbuch. II. E. Schweizerbartische Verlagsbuch, Stuttgart, Germany. 
Schilsky, J. 1894. Die Käfer Europa's. Nach der Natur beschrieben von Dr. H.C. Küster und Dr. G. Kraatz. Fortgesetzt von J. Schilsky. Dreissigstes Heft. Bauer und Raspe, Nürnberg, Germany.

Schilsky, J. 1895. Die Käfer Europa's. Nach der Natur beschrieben von Dr. H.C. Küster und Dr. G. Kraatz. Fortgesetzt von J. Schilsky. Einunddreissigstes Heft. Bauer und Raspe, Nürnberg, Germany.

Schilsky, J. 1898. Die Käfer Europa's. Nach der Natur beschrieben von Dr. H.C. Küster und Dr. G. Kraatz. Fortgesetzt von J. Schilsky. Fünfunddreissigstes Heft. Bauer und Raspe, Nürnberg, Germany.

Schilsky, J. 1899. Die Käfer Europa's. Nach der Natur beschrieben von Dr. H.C. Küster und Dr. G. Kraatz. Fortgesetzt von J. Schilsky. Sechsunddreissigstes Heft. Bauer und Raspe, Nürnberg, Germany.

Selnekovič, D. 2020. Mordellidae. Album: 72157713106384203, photographs: 49793545186, 49792999178 [online]. Available from: https:/www.flickr.com/photos/186739435@N08/ albums/72157713106384203 [accessed 22 June 2020].

Selnekovič, D. and Improta, R. 2020. The type material of Mordellidae described by Achille Costa (Coleoptera: Tenebrionoidea). Zootaxa, 4803: 042-050. https://doi.org/10.11646/ zootaxa.4803.1.2.

Selnekovič, D. and Kodada, J. 2019. Taxonomic revision of Mordellistena hirtipes species complex with new distribution records (Insecta, Coleoptera, Mordellidae). ZooKeys, 854: 89-118. https://doi.org/10.3897/zookeys.854.32299.

Selnekovič, D. and Ruzzier, E. 2019. New distributional records for sixteen Mordellidae species from the Western Palearctic (Insecta, Coleoptera, Mordellidae). ZooKeys, 894: 151-170. https://doi.org/10.3897/zookeys.894.39584.

Swan, D.C. 1936. Berlese's fluid: remarks upon its preparation and use as a mounting medium. Bulletin of Entomological Research, 27: 389-391.

Winkler, A. 1928. Part 8. In Catalogus Coleopterorum regionis palaearcticae. A. Winkler, Vienna, Austria. Pp. 625-752.

Woodcock, T.S., Boyle, E.E., Roughley, R.E., Kevan, P.G., Labbee, R.N., Smith, A.B.T., et al. 2013. The diversity and biogeography of the Coleoptera of Churchill: insights from DNA barcoding. BMC Ecology, 13: 40. https://doi.org/10.1186/1472-6785-13-40.

Cite this article: Selnekovič, D., Goffová, K., Kodada, J., and Improta, R. 2021. Revealing the identity of Mordellistena minima and M. pseudorhenana (Coleoptera: Mordellidae) based on re-examined type material and DNA barcodes, with new distributional records and comments on morphological variability. The Canadian Entomologist, 153: 343-367. https:// doi.org/10.4039/tce.2021.3. 